\title{
Effect of Blending Ratios from Pineapple Juice on Storage, Physicochemical, Antiradical Activity and Volatile Compounds of Two Cactus Pear Juices
}

\author{
Gamil El Sayed Ibrahim 1므, Mahmoud Elwakeel ${ }^{2}{ }^{\mathbb{D}}$, Ahmed M. S. Hussein ${ }^{3 \mathbb{C}}$ \\ 1 Chemistry of Aroma and Flavor Dept., National Research Centre, Dokki 12622, Cairo, Egypt; \\ gamilemad2000@gmail.com (G.S.I.); \\ 2 Food Science Department, Faculty of Agriculture, Beni-Suef University, Beni-Suef 62511, Egypt; \\ elwakeeel@hotmail.com (M.E.); \\ 3 Food Technology Dept., National Research Centre, Dokki 12622, Cairo, Egypt; a_said22220@yahoo.com (A.M.S.H.); \\ * Correspondence: gamilemad2000@gmail.com (G.S.I.);
}

Scopus Author ID 56014475200

Received: 28.06.2021; Revised: 15.09.2021; Accepted: 20.09.2021; Published: 31.10.2021

\begin{abstract}
The current study was carried out to evaluate the effect of blending ratio and storage of mixed fruit juice from pineapple and two cactus pear juices. The data for $\mathrm{pH}$ and titratable acidity (TA) showed a reverse relationship (while $\mathrm{pH}$ decreased; an increase in TA occurred in non-significant values) in both blends at all blending ratios with excellent antimicrobial activity. The studied blends had HMF concentrations ranging from 1.04 to $2.49 \mathrm{mg} / \mathrm{L}$ at $\mathrm{T} 1$ (at zero time) and $\mathrm{T} 6$ (at the end of storage), respectively. The total phenolic concentration was $28.53,59.72$, and $51.46 \mathrm{mg} / 100 \mathrm{~mL}$ of the initial pineapple, purple, and green $\mathrm{CP}$ juices, respectively. The blends of pineapple with purple $\mathrm{CP}$ showed a higher total antioxidant activity than pineapple with green $\mathrm{CP}$ juice. T6 blend amongst all blends was found to be the most preferred one. Therefore, we follow up the organoleptic evaluation and volatile compounds using GC-MS of this blend during storage. The main volatile compounds identified using GC-MS in fresh, pure pineapple juice were esters, especially ethyl acetate, methyl 2-methylbutanoate, and ethyl butanoate, representing $13.11 \%, 9.32 \%$, and $8.38 \%$, respectively. On the other hand, the major volatile compounds were alcohols followed by aldehydes. 1-Hexanol had the highest concentration $(12.41 \%)$, followed by hexanal $(10.86 \%)$. The stored blend of pineapple and purple CP (1:3) exhibited a remarkable increase in aldehydes, especially benzaldehyde, to be $10.93 \%$ compared to the fresh blend, which had $7.62 \%$.
\end{abstract}

Keywords: pineapple; cactus pear; blends; physicochemical; volatile; storage.

(C) 2021 by the authors. This article is an open-access article distributed under the terms and conditions of the Creative Commons Attribution (CC BY) license (https://creativecommons.org/licenses/by/4.0/).

\section{Introduction}

The pineapple fruit is the most important tropical one apart from mango, banana, and passion fruits [1]. The most common forms for consumption of pineapple are drinks, juice, and nectar because of its pleasant flavor and aroma [2]. The edible part in pineapple accounts for about $60 \%$, with moisture content approximately $85 \%$ [3]. The consumption of fresh pineapple fruits reaches about $70 \%$ in the origin country. In developed countries, the processed pineapple may be juice, crushed, sliced, or chunks. The blending of pineapple juice with fruits or vegetable juices gives a new flavor to developed drinks or juices [4]. The quality and shelf-life of untreated pineapple juice-about 3 days at refrigerator- depend on the quality of raw materials and applied processes [5]. The deterioration of physicochemical properties and quality loss of 
pineapple juice makes consumers reject it due to browning from enzymes activity and the destruction of carotenoids and ascorbic acid [6]. Also, the high moisture content makes pineapple products easy to microbial spoilage, and the seasonal problem has driven workers in food processing and researchers to find novel preservation methods for consuming in the offseason [7].

Cactus pear or opuntia fig is a member of the cactus family that originates from Mexico and is grown in many tropical or subtropical countries like Egypt. It is an excellent plant for regions with limited water resources for medicinal and industrial applications and farm-based industries [8]. Cactus pear fruits are a rich source for vitamins such as $\mathrm{C}, \mathrm{E}, \mathrm{A}$, and $\mathrm{B}_{1}$ and $\mathrm{B}_{2}$; minerals like iron, phosphorus, magnesium, potassium, and calcium; bioactive compounds, i.e., anthocyanins, flavonoids, polyphenols, and betalains [9]. The color of fruits ranged from yellow to purple depending on betalains concentration present in pulp and epidermis [10]. The attractive color and pleasant taste due to high sugar content and delicious flavors encourage consumers to eat fresh and processed products. In addition, the health effects of pulp like reducing LDL cholesterol level, reduction of weight, anticancer may be due to the presence of high concentrations of phytochemical compounds in fruits pulp [11]. Several products have been found from cactus pears like juice [12], essential oil and gum [13, 14], dessert [15], and food additives [16, 17]. However, the high water content of about 93\% (fresh mass), as well as rich content of sugars, especially fructose, glucose, and sucrose, which represent about $50 \%$ (dry mass), and approximately neutral $\mathrm{pH}$, make the fresh fruits easy to microbial attack and fermentation which leads to fruits spoilage.

The decreased demand for chemical preservatives in food products due to their hazardous effects on long-time consumption encouraged searching for novel methods for food preservation [18]. The fruit juice blends have been widely marketed due to their palatable flavor, unique aroma as well as improvement of organoleptically and nutritional quality [19]. The blends formulation may include fruit juices or fruits and vegetable juices or improve the blend quality by adding minerals, herbs, spices, or vitamins. The finished blend quality depends on the ratio of blending, kind, and quality of fruit or vegetables. The blending ratio plays an important role in the physicochemical and sensory quality of the blend [20, 21].

Flavors play an imperative role in the quality of fruits and their products and determine the quality of processed and fresh products [22]. Numerous volatile compounds had been identified in fresh pineapple, cactus pear fruits, and their derivatives [23, 24]. However, no research on the volatile composition of juice blend from pineapple and cactus pear is available. Therefore, the current study aimed to evaluate the blending ratios and storage effect on the physicochemical, antiradical activity, antimicrobial activity, and volatile compounds of blends from pineapple juice with two cactus pear juices.

\section{Materials and Methods}

\subsection{Materials for juice extraction and preparation of blends.}

Pineapple fruits were obtained from the local market at Dokki, Giza, Egypt. Cactus pears fruit $O$. ficus-indica (green) and $O$. lindheimeri (purple) were obtained from a private farm at Alexandria Governorate, Egypt, during the 2019-2020 seasons. To prepare pineapple juice, the ripe fruits were respectively washed under running water, drained in colanders, peeled, and diced into cubes. The shell and core of the pineapple were removed using a sharp stainless steel knife, the flesh was cut into small pieces, and the juice was extracted. The juice 
of the edible parts of the respective fruits was extracted separately using a juice extractor (in a Moulinex blender (type LM2421 41, France). The preparation of cactus pear juice and blending with pineapple juice was carried out as described by [25] and given in Table 1.

Table 1. Formulation of pineapple juice with two cactus pear juices.

\begin{tabular}{l|l|l} 
Sample code & Juice & ratio \\
\hline T1 & Pineapple & 100 \\
\hline T2 & Purple cactus pear (purple CP) & 100 \\
\hline T3 & Green cactus pear (green CP) & 100 \\
\hline T4 & Pineapple : purple CP & $1: 3$ \\
\hline T5 & Pineapple & $1: 1$ \\
\hline T6 & Pineapple & $3: 1$ \\
\hline T7 & Pineapple : green CP & $1: 3$ \\
\hline T8 & Pineapple & $1: 1$ \\
\hline T9 & Pineapple & $3: 1$
\end{tabular}

\subsubsection{Storage conditions.}

The blended juice samples were packaged in $200 \mathrm{ml}$ sterilized glass bottles at about $80^{\circ} \mathrm{C}$ for 10 minutes. They were stored in a refrigerator; samples were subjected for analysis at different intervals (zero, 2, 4, 8, and 14) days of storage.

2.1.2. Chemicals and reagents.

DPPH (2,2'-diphenyl-1-picrylhydrazyl), HMF, ABST, quercetin, ethanol, FolinCiocalteu's reagent, and hexane was obtained from Sigma-Aldrich (Germany). All other reagents and chemicals were of analytical grade.

\subsection{Physicochemical analysis.}

\subsection{1. $\mathrm{pH}$.}

The $\mathrm{pH}$ of the juice samples was determined using a digital $\mathrm{pH}$ meter (Hanna $\mathrm{pH}$-meter HI $9021 \mathrm{~m}$ Germany) according to [26]. Fifty (50 ml) of the juice was transferred into a beaker, and the $\mathrm{pH}$ was determined after the meter was calibrated using standard buffer solutions of $\mathrm{pH} 4.0$ and 7.0. Sufficient time was allowed for equilibration before readings were taken. The determinations were carried out in triplicates.

\subsubsection{Titratable acidity.}

Briefly, $10 \mathrm{~mL}$ of each sample was mixed with $40 \mathrm{~mL}$ of distilled water. The $\mathrm{pH}$ electrode was pushed into the mixture and measured under continuous stirring. Each sample was titrated with $0.1 \mathrm{~mol} / \mathrm{L} \mathrm{NaOH}$ to the endpoint of $8.2(\mathrm{pH})$, and the amount $(\mathrm{mL})$ of $\mathrm{NaOH}$ used was recorded. Titratable acidity was expressed in the percentage of citric acid and calculated using the following Eq.

Titratable acidity $\%=([\mathrm{mL} \mathrm{NaOH}$ used $] \times 0.064 \times$ molarity of $\mathrm{NaOH} \times 100)$

(Volume of sample).

It was determined by means of three replicates; the results were expressed as $\mathrm{g} / 100 \mathrm{ml}$ with reference to citric acid [27]. 
2.2.3. Total soluble solids (TSS).

The handheld sugar refractometer was used, the prism of the refractometer was cleaned, and a drop of the juice was placed on the prism and closed. The total soluble solids (TSS) were read off the refractometer scale when held close to the eye according to the method of [26].

\subsubsection{Browning index and 5-hydroxymethylfurfural (HMF) analysis.}

The browning index analysis (BI) was measured using the method of [28]. Briefly, 10 $\mathrm{mL}$ of each juice sample was centrifuged (10 min, $1700 \mathrm{xg}$ ) (6500, Hamilton Bell, New Jersey, USA) to remove coarse particles and then $5 \mathrm{~mL}$ of ethyl alcohol (95\%, Sigma-Aldrich, Dublin, Ireland) were added to $5 \mathrm{~mL}$ of supernatant before centrifugation was repeated. The absorbance of the obtained supernatant was measured at $420 \mathrm{~nm}$ using a spectrophotometer.

To determine the HMF content, $2 \mathrm{ml}$ of the juice sample was introduced into a $16 \mathrm{ml}$ screw cap tube. Two $\mathrm{ml}$ of $12 \% \mathrm{w} / \mathrm{w}$ trichloroacetic acid (TCA) and $2 \mathrm{ml}$ of $0.025 \mathrm{M}$ thiobarbituric acid were subsequently added and mixed thoroughly. The tubes with the sample were then placed in the water bath at $40{ }^{\circ} \mathrm{C}\left( \pm 0.5^{\circ} \mathrm{C}\right)$. After incubating for $50 \mathrm{~min}$, the tubes were cooled immediately using tap water, and the absorbance was measured at $443 \mathrm{~nm}$ [29]. A calibration curve of HMF was utilized to quantify the HMF concentration.

\subsubsection{Stability analysis.}

Determination of juice stability was performed according to [30]. In brief, $10 \mathrm{~mL}$ of juice was centrifuged (Hamilton Bell Clinical Centrifuge, model 6500) at $1850 \mathrm{xg}$ for $20 \mathrm{~min}$, and stability was expressed as the percentage $(\mathrm{w} / \mathrm{w})$ of settled solids obtained after centrifugation.

\subsection{Phytochemical determination and antioxidant activity assays.}

\subsubsection{Preparation of extracts.}

The extracts from fruit juice blends were prepared as described by [31]. About $10 \mathrm{ml}$ of each sample were extracted with $10 \mathrm{~mL}$ of ethanol. Extraction was carried out under stirring for $1 \mathrm{~h}$ at room temperature in the dark. Each extract was centrifuged for $30 \mathrm{~min}$ at $900 \times \mathrm{g}$ at $4^{\circ} \mathrm{C}$. The supernatant (ethanolic extract) was then collected and kept in the dark before further testing.

\subsubsection{Total phenolic content (TPC).}

The total polyphenolic content was determined utilizing the Folin-Ciocalteu method [32]. Here, $900 \mu \mathrm{L}$ of distilled water and $100 \mu \mathrm{L}$ of Folin-Ciocalteu reagent were added to 100 $\mu \mathrm{L}$ of the tested extracts. The solutions were mixed and put aside. After $4 \mathrm{~min}, 1 \mathrm{~mL}$ of $7.7 \%$ sodium bicarbonate and $400 \mu \mathrm{L}$ of distilled water were added. The content was mixed and placed in a water bath $\left(40{ }^{\circ} \mathrm{C}\right)$ for $50 \mathrm{~min}$. After this, the absorbance of the solutions was measured using a UV-VIS spectrometer at a wavelength of $765 \mathrm{~nm}$. The total polyphenols content in the tested extracts was expressed as gallic acid equivalents (mg GAE/100 mL juice).

2.3.3. Total flavonoid content (TFC). 
The total flavonoid content of the samples was determined by applying a colorimetric method [33]. $2.0 \mathrm{~mL}$ extract was added to $2.0 \mathrm{~mL} \mathrm{AlCl}_{3}$ reagent (2\%) in ethanol. Absorbance was recorded at $420 \mathrm{~nm}$ after $30 \mathrm{~min}$ incubation at room temperature against ethanol blank. A calibration curve with quercetin standards in ethanol $(10-120 \mathrm{ug} / \mathrm{mL})$ was developed. All assays were repeated three times $(n=3)$. Total flavonoid content was expressed as ug QE/100 $\mathrm{mL}$ juice (mean \pm standard deviation) (QE: quercetin equivalents).

\subsubsection{Total carotenoid contents (TCC).}

The total carotenoids were extracted in a mixture of hexane-acetonitrile-ethanol [50:25:25 (v:v:v)]. About $1 \mathrm{ml}$ of sample was extracted with $50 \mathrm{ml}$ of the solvent mixture. The mixture was stirred (15 min) on a magnetic stirring plate in the dark to extract the carotenoids. Distilled water $(3 \mathrm{ml})$ was added to the mixture and stirred further for $5 \mathrm{~min}$, after which it was allowed to settle for $5 \mathrm{~min}$ to have phase separation. The absorbance of the filtered hydrophobic phase was measured at $450 \mathrm{~nm}$ using hexane as blank [34].

\subsubsection{DPPH radical scavenging assay.}

The antioxidant capacity of the tested blends was measured using a $0.1 \mathrm{mM}$ methanol solution of the DPPH stable radical (2,2'-diphenyl-1-picrylhydrazyl). Absorbance was measured at $517 \mathrm{~nm}$ wavelength, and the UV-VIS spectrophotometer was calibrated to pure methanol. In the following step, the absorbance of the samples containing $2.5 \mathrm{~mL}$ of DPPH solution and $0.5 \mathrm{~mL}$ of the extract was assessed [35]. Based on the results, the free radical scavenging ability of the tested extracts was calculated using the following formula:

$$
\% \mathrm{RSA}=\left[\left(\mathrm{A}_{0}-\mathrm{A}_{1}\right) / \mathrm{A}_{0}\right] \times 100
$$

where: $A_{0}$ is the absorbance of the sample except tested extracts, $A_{1}$ is the absorbance of the sample with tested extracts. Results are presented in $\mathrm{EC}_{50}$ values, representing the weight of the sample required to scavenge $50 \%$ of the DPPH radicals available.

\subsubsection{ABTS radical scavenging assay.}

The 2,2'-azino-bis(3-ethylbenzothiazoline-6-sulfonic acid) (ABTS) assay was carried out as stated by [36]. Afterward, $7 \mathrm{mM}$ of ABTS (Sigma) was mixed (1:1) with $2.45 \mathrm{mM}$ of potassium persulfate (Sigma). The mix was kept for 12-16 h at room temperature in the dark to generate free radicals $\left(\mathrm{ABTS}^{*+}\right)$. The $\mathrm{ABTS}^{*+}$ solution was then diluted in ethanol $(1: 100)$ to obtain $0.7 \pm 0.02$ absorbance units $(734 \mathrm{~nm})$, measured by a spectrophotometer. Next, $10 \mu \mathrm{L}$ of juice was mixed with $990 \mu \mathrm{L}$ of ABTS $^{*+}$ solution; the absorbance was measured at $734 \mathrm{~nm}$. A standard curve $(20-150 \mu \mathrm{M})$ was constructed using 6-hydroxy-2, 5,7,8-tetramethylchroman2-carboxylic acid (Trolox, Sigma) and the ABTS $^{*+}$ scavenge value was obtained by interpolation from a linear regression analysis. The results were expressed in $\mu \mathrm{M}$ Trolox equivalent antioxidant capacity/100mL juice (TE). All the samples were analyzed in triplicate.

\subsection{Microbiological evaluation.}

Tested samples were subjected to microbiological analysis. Total viable bacterial count, yeasts, and molds were enumerated according to [37]. Nutrient agar (NA) medium was used for the cultivation and for a total viable count of bacterial strains, The $\mathrm{pH}$ was adjusted to 7.4, and the medium was sterilized at $121{ }^{\circ} \mathrm{C}$ for 15 minutes. Yeast and molds were maintained on 
the Potato dextrose agar (PDA) were prepared, autoclaved (at 15 psi for 15 minutes), and poured into autoclaved Petri plates. After sterilization at $121{ }^{\circ} \mathrm{C}$ for 15 minutes, the medium was acidified to $\mathrm{pH} 3.5$ by adding $1.0 \mathrm{ml}$ of tartaric acid (10\%) to every $100 \mathrm{ml}$ of the sterilized medium at $50^{\circ} \mathrm{C}$. The media were left to solidify in the laminar airflow. Juice samples were serially diluted in sterile $(0.1 \%)$ peptone water and spread over the solidified agar plates. The plates were incubated for 24 hours at $37^{\circ} \mathrm{C}$. After incubation, the number of colonies was counted and recorded.

\subsection{Organoleptic evaluation.}

To estimate consumers' acceptability, the following sensory attributes were investigated: color, appearance, taste, flavor, consistency, and overall acceptability. A ninepoint structured hedonic scale test $(9=$ extremely like $-1=$ extremely dislike $)$ was used to assess overall acceptance. For the investigation, the samples were served in a sequential manner in cups containing $25 \mathrm{~mL}$ of the blended juice and codified with three random digits. The sensory evaluation was conducted with ten judges in Food Industry and Nutrition research Division at the national research Centre [38].

\subsection{Volatile compounds analysis.}

\subsubsection{Extraction of volatile compounds.}

Volatile compounds were extracted from the selected blend T6 (fresh and stored) and fresh pineapple and purple cactus pear juices by HS-SPME. An SPME device (Supelco, Bellefonte, PA, USA) with a $10 \mathrm{~mm}$ fiber coated with $100 \mu \mathrm{m}$ of polydimethylsiloxane was used for the extraction. The extraction was performed using the headspace mode ( $20 \mathrm{~mm}$ from the liquid surface) at $50^{\circ} \mathrm{C}$ for $15 \mathrm{~min}$ with shaking (250 rpm).

2.6.2. Analysis by gas chromatography with mass spectrometry detection (GC-MS).

After the extraction, the SPME device was introduced in the splitless injector of a 7890A gas chromatograph (Agilent Technologies Inc., USA) at $230{ }^{\circ} \mathrm{C}$ for $5 \mathrm{~min}$. The initial oven temperature was $40^{\circ} \mathrm{C}$ and increased to $230^{\circ} \mathrm{C}$ at $5^{\circ} \mathrm{C} / \mathrm{min}$ for $5 \mathrm{~min}$. It was then increased to $300{ }^{\circ} \mathrm{C}$ at a rate of $20^{\circ} \mathrm{C} / \mathrm{min}$ for $3 \mathrm{~min}$. Helium flow $(99.99 \%$ purity, $1 \mathrm{~mL} / \mathrm{min})$ was the carrier, using a DB-5MS capillary column (60 m long, $250 \mu \mathrm{m}$ diameter, $0.25 \mu \mathrm{m}$ wide phase; Agilent Technologies Inc., USA). The volatile compounds were identified with a 5975C quadrupole mass analyzer (Agilent Technologies Inc., USA), using the following specifications: EI mode at $70 \mathrm{eV}$, gain factor 1, transference line temperature $\left(250{ }^{\circ} \mathrm{C}\right)$, ionization source $\left(230^{\circ} \mathrm{C}\right)$, and quadrupole $\left(150^{\circ} \mathrm{C}\right)$. The mass range was $30-800 \mathrm{u}$; 住 were compared with NIST/EPA/NIH Mass Spectra Library database v1.7 (USA). The volatile compounds were positively identified by comparing Kovats retention indices [39].

\subsection{Statistical analysis.}

Results were expressed as mean values and standard deviation of three (3) determinations. Data were analyzed using a one-way analysis of variance (ANOVA) using Statistical Package for Social Science (SPSS) version 16.0 software 2010 to test the level of significance at $5 \%$ probability $(P<0.05)$. Duncan's New Multiple Range Test was used to separate the means where significant differences existed according to the method of [40]. 


\section{Results and Discussion}

Data in Table 2 revealed the blending ratio and storage effect on some physicochemical properties of pineapple juice when blending with two cactus pear juices (purple and green). At the storage beginning, pineapple, purple and green cactus pear juices had $\mathrm{pH}$ values 3.45, 6.02, and 5.98, respectively (Table 2). Our data is in agreement with [41], who found that both Egyptian prickly pear red and orange-yellow had approximately neutral $\mathrm{pH}$ values of 6.14 and 6.20 , respectively. On the other hand, Karabagias et al. [42] mentioned prickly pear juice had less $\mathrm{pH}(3.40 \pm 0.1)$ than found in our study.

These data revealed that pineapple juice is more acidic compared to colored cactus pars juices. With the decrease of pineapple in blending, a decrease in $\mathrm{pH}$ occurred. Our data, in parallel with [1] results, showed a remarkable decrease in $\mathrm{pH}$ of blend prepared from pineapple and mango.

Table 2. Storage and blending ratio effect of pineapple juice with two cactus pear juices on physicochemical

\begin{tabular}{|c|c|c|c|c|c|c|c|}
\hline Storage time & Sample & pH & TA & TSS & BI & $\begin{array}{l}\text { 5-HMF } \\
(\mathrm{mg} / \mathrm{L})\end{array}$ & $\begin{array}{l}\text { Cloud } \\
\text { stability }\end{array}$ \\
\hline \multirow[t]{9}{*}{ Day 0} & $\mathrm{~T} 1$ & $3.45 \pm 0.12^{\mathrm{a}}$ & $0.68 \pm 0.05^{\mathrm{a}}$ & $11.17 \pm 0.19^{\mathrm{a}}$ & $0.24 \pm 0.01^{\mathrm{a}}$ & $1.04 \pm 0.02^{\mathrm{a}}$ & $38.7 \pm 0.29^{a}$ \\
\hline & $\mathrm{T} 2$ & $6.02 \pm 0.16^{\mathrm{b}}$ & $0.41 \pm 0.06^{\mathrm{b}}$ & $12.78 \pm 0.13^{\mathrm{b}}$ & $0.39 \pm 0.02^{\mathrm{b}}$ & $2.36 \pm 0.07^{\mathrm{b}}$ & $45.3 \pm 0.37^{\mathrm{b}}$ \\
\hline & T3 & $5.98 \pm 0.28^{\mathrm{c}}$ & $0.59 \pm 0.02^{\mathrm{c}}$ & $11.39 \pm 0.16^{\mathrm{a}}$ & $0.31 \pm 0.03^{\mathrm{c}}$ & $1.82 \pm 0.05^{\mathrm{c}}$ & $42.6 \pm 0.19^{\mathrm{c}}$ \\
\hline & $\mathrm{T} 4$ & $5.86 \pm 0.31^{\mathrm{d}}$ & $0.44 \pm 0.01^{\mathrm{d}}$ & $13.92 \pm 0.08$ & $0.43 \pm 0.08$ & $2.38 \pm 0.06^{\mathrm{d}}$ & $48.3 \pm 0.12^{\mathrm{d}}$ \\
\hline & T5 & $5.84 \pm 0.16^{\mathrm{e}}$ & $0.46 \pm 0.03^{\mathrm{d}}$ & $13.94 \pm 0.14^{\mathrm{b}}$ & $0.45 \pm 0.07^{\mathrm{d}}$ & $2.39 \pm 0.08^{\mathrm{d}}$ & $48.9 \pm 0.24^{\mathrm{d}}$ \\
\hline & T6 & $5.84 \pm 0.07^{\mathrm{e}}$ & $0.45 \pm 0.05^{\mathrm{d}}$ & $13.95 \pm 0.16^{\mathrm{b}}$ & $0.46 \pm 0.06^{\mathrm{d}}$ & $2.40 \pm 0.03$ & $50.2 \pm 0.16^{\mathrm{e}}$ \\
\hline & $\mathrm{T} 7$ & $5.79 \pm 0.19^{f}$ & $0.51 \pm 0.09^{\mathrm{e}}$ & $12.89 \pm 0.19^{c}$ & $0.41 \pm 0.03$ & $1.85 \pm 0.01^{\mathrm{e}}$ & $44.7 \pm 0.28$ \\
\hline & $\mathrm{T} 8$ & $5.79 \pm 0.12^{\mathrm{f}}$ & $0.51 \pm 0.04^{\mathrm{e}}$ & $12.90 \pm 0.17^{\mathrm{c}}$ & $0.42 \pm 0.01^{\mathrm{e}}$ & $1.85 \pm 0.04^{\mathrm{e}}$ & $45.6 \pm 0.12^{\mathrm{f}}$ \\
\hline & T9 & $5.78 \pm 0.14^{f}$ & $0.50 \pm 0.07^{\mathrm{e}}$ & $12.91 \pm 0.21^{\mathrm{a}}$ & $0.42 \pm 0.02^{\mathrm{e}}$ & $1.87 \pm 0.08^{\mathrm{g}}$ & $46.2 \pm 0.15^{\mathrm{f}}$ \\
\hline \multirow[t]{9}{*}{ Day 2} & $\mathrm{~T} 1$ & $3.39 \pm 0.16$ & $0.69 \pm 0.01^{\mathrm{a}}$ & $12.38 \pm 0.13^{\mathrm{b}}$ & $0.27 \pm 0.07$ & $1.16 \pm 0.09^{\mathrm{g}}$ & $32.5 \pm 0.31^{\mathrm{f}}$ \\
\hline & $\mathrm{T} 2$ & $5.79 \pm 0.18^{\mathrm{f}}$ & $0.42 \pm 0.03$ & $13.64 \pm 0.18^{\mathrm{d}}$ & $0.40 \pm 0.05$ & $2.38 \pm 0.07^{\mathrm{d}}$ & $41.3 \pm 0.12^{\mathrm{g}}$ \\
\hline & T3 & $5.86 \pm 0.19^{d}$ & $0.50 \pm 0.08$ & $12.71 \pm 0.16^{\mathrm{b}}$ & $0.38 \pm 0.01$ & $1.84 \pm 0.04$ & $39.8 \pm 0.14$ \\
\hline & $\mathrm{T} 4$ & $5.84 \pm 0.11^{\mathrm{e}}$ & $0.45 \pm 0.07^{\mathrm{d}}$ & $13.90 \pm 0.15^{\mathrm{b}}$ & $0.44 \pm 0.03^{\mathrm{f}}$ & $2.41 \pm 0.06^{\mathrm{f}}$ & $47.6 \pm 0.13$ \\
\hline & T5 & $5.83 \pm 0.13^{\mathrm{e}}$ & $0.45 \pm 0.06^{\mathrm{d}}$ & $13.92 \pm 0.12^{\mathrm{b}}$ & $0.46 \pm 0.02^{\mathrm{d}}$ & $2.43 \pm 0.02^{\mathrm{f}}$ & $48.2 \pm 0.19^{\mathrm{d}}$ \\
\hline & T6 & $5.82 \pm 0.16^{\mathrm{e}}$ & $0.46 \pm 0.08^{\mathrm{d}}$ & $13.93 \pm 0.19^{c}$ & $0.47 \pm 0.07^{\mathrm{d}}$ & $2.43 \pm 0.01^{\mathrm{f}}$ & $49.7 \pm 0.25^{\mathrm{d}}$ \\
\hline & $\mathrm{T} 7$ & $5.74 \pm 0.14$ & $0.52 \pm 0.01^{\mathrm{e}}$ & $12.86 \pm 0.14^{\mathrm{c}}$ & $0.42 \pm 0.06$ & $1.86 \pm 0.06^{\mathrm{e}}$ & $43.8 \pm 0.19$ \\
\hline & $\mathrm{T} 8$ & $5.72 \pm 0.16$ & $0.53 \pm 0.02^{\mathrm{e}}$ & $12.87 \pm 0.12^{\mathrm{c}}$ & $0.44 \pm 0.07^{\mathrm{f}}$ & $1.88 \pm 0.03^{\mathrm{g}}$ & $44.5 \pm 0.12^{\mathrm{b}}$ \\
\hline & T9 & $5.71 \pm 0.12$ & $0.53 \pm 0.08^{\mathrm{e}}$ & $12.87 \pm 0.11^{\mathrm{c}}$ & $0.44 \pm 0.03^{\mathrm{f}}$ & $1.88 \pm 0.02^{g}$ & $45.2 \pm 0.14^{\mathrm{b}}$ \\
\hline \multirow[t]{9}{*}{ Day 4} & $\mathrm{~T} 1$ & $3.25 \pm 0.18$ & $0.70 \pm 0.05$ & $11.98 \pm 0.10^{\mathrm{f}}$ & $0.32 \pm 0.01^{\mathrm{c}}$ & $1.21 \pm 0.05$ & $46.7 \pm 0.06$ \\
\hline & $\mathrm{T} 2$ & $5.83 \pm 0.12^{\mathrm{e}}$ & $0.44 \pm 0.07$ & $13.54 \pm 0.09$ & $0.42 \pm 0.02^{\mathrm{e}}$ & $2.41 \pm 0.09$ & $39.4 \pm 0.17$ \\
\hline & $\mathrm{T} 3$ & $5.74 \pm 0.19$ & $0.53 \pm 0.02^{\mathrm{e}}$ & $12.69 \pm 0.12$ & $0.40 \pm 0.07$ & $1.92 \pm 0.08$ & $37.5 \pm 0.05$ \\
\hline & $\mathrm{T} 4$ & $5.82 \pm 0.08^{\mathrm{e}}$ & $0.46 \pm 0.06^{\mathrm{d}}$ & $13.87 \pm 0.13$ & $0.45 \pm 0.05$ & $2.45 \pm 0.07^{\mathrm{h}}$ & $46.2 \pm 0.13$ \\
\hline & T5 & $5.80 \pm 0.12^{\mathrm{f}}$ & $0.47 \pm 0.07^{\mathrm{d}}$ & $13.90 \pm 0.14^{\mathrm{b}}$ & $0.47 \pm 0.02^{\mathrm{d}}$ & $2.45 \pm 0.01^{\mathrm{h}}$ & $47.6 \pm 0.18$ \\
\hline & T6 & $5.79 \pm 0.13^{\mathrm{f}}$ & $0.48 \pm 0.05$ & $13.90 \pm 0.19^{b}$ & $0.46 \pm 0.04^{\mathrm{d}}$ & $2.46 \pm 0.06^{\mathrm{h}}$ & $48.3 \pm 0.21^{\mathrm{d}}$ \\
\hline & $\mathrm{T} 7$ & $5.70 \pm 0.19$ & $0.53 \pm 0.04^{\mathrm{f}}$ & $12.85 \pm 0.21^{\mathrm{c}}$ & $0.43 \pm 0.03$ & $1.92 \pm 0.04$ & $42.5 \pm 0.19$ \\
\hline & $\mathrm{T} 8$ & $5.69 \pm 0.21$ & $0.54 \pm 0.03^{\mathrm{f}}$ & $12.85 \pm 0.12^{\mathrm{c}}$ & $0.45 \pm 0.01$ & $1.93 \pm 0.03$ & $43.6 \pm 0.13$ \\
\hline & T9 & $5.68 \pm 0.24$ & $0.54 \pm 0.01^{\mathrm{f}}$ & $12.86 \pm 0.16^{\mathrm{c}}$ & $0.45 \pm 0.03$ & $1.94 \pm 0.05$ & $44.9 \pm 0.14^{\mathrm{b}}$ \\
\hline \multirow[t]{9}{*}{ Day 8} & $\mathrm{~T} 1$ & $2.93 \pm 0.15$ & $0.73 \pm 0.09$ & $11.75 \pm 0.18$ & $0.39 \pm 0.09^{\mathrm{b}}$ & $1.25 \pm 0.07$ & $49.2 \pm 0.08$ \\
\hline & $\mathrm{T} 2$ & $5.76 \pm 0.16$ & $0.46 \pm 0.02^{\mathrm{d}}$ & $13.51 \pm 0.12$ & $0.46 \pm 0.07$ & $2.43 \pm 0.01^{\mathrm{f}}$ & $41.3 \pm 0.11$ \\
\hline & T3 & $5.86 \pm 0.12$ & $0.51 \pm 0.03^{\mathrm{e}}$ & $12.64 \pm 0.31$ & $0.44 \pm 0.01$ & $1.95 \pm 0.06^{\mathrm{j}}$ & $40.6 \pm 0.15$ \\
\hline & $\mathrm{T} 4$ & $5.79 \pm 0.08^{\mathrm{f}}$ & $0.47 \pm 0.07^{\mathrm{d}}$ & $13.85 \pm 0.25$ & $0.48 \pm 0.06$ & $2.47 \pm 0.04$ & $47.5 \pm 0.16$ \\
\hline & $\mathrm{T} 5$ & $5.68 \pm 0.13$ & $0.48 \pm 0.06$ & $13.88 \pm 0.17^{\mathrm{g}}$ & $0.49 \pm 0.05$ & $2.48 \pm 0.05$ & $48.2 \pm 0.47^{\mathrm{d}}$ \\
\hline & T6 & $5.67 \pm 0.12$ & $0.48 \pm 0.05$ & $13.89 \pm 0.12^{\mathrm{g}}$ & $0.50 \pm 0.02$ & $2.48 \pm 0.01$ & $49.3 \pm 0.24^{\mathrm{d}}$ \\
\hline & $\mathrm{T} 7$ & $5.64 \pm 0.19$ & $0.54 \pm 0.04^{\mathrm{e}}$ & $12.81 \pm 0.19$ & $0.45 \pm 0.03$ & $1.95 \pm 0.09$ & $45.7 \pm 0.22^{\mathrm{b}}$ \\
\hline & $\mathrm{T} 8$ & $5.61 \pm 0.14$ & $0.55 \pm 0.01$ & $12.82 \pm 0.11$ & $0.46 \pm 0.01$ & $1.96 \pm 0.07$ & $47.8 \pm 0.19$ \\
\hline & T9 & $5.59 \pm 0.17$ & $0.56 \pm 0.02$ & $12.83 \pm 0.18$ & $0.47 \pm 0.08^{\mathrm{d}}$ & $1.97 \pm 0.05$ & $49.3 \pm 0.31^{\mathrm{d}}$ \\
\hline \multirow[t]{7}{*}{ Day 14} & $\mathrm{~T} 1$ & $2.91 \pm 0.15$ & $0.75 \pm 0.03$ & $11.35 \pm 0.24$ & $0.43 \pm 0.02$ & $1.28 \pm 0.04$ & $49.4 \pm 0.28^{d}$ \\
\hline & $\mathrm{T} 2$ & $5.73 \pm 0.19$ & $0.48 \pm 0.09$ & $13.41 \pm 0.08$ & $0.51 \pm 0.03$ & $2.45 \pm 0.01$ & $42.5 \pm 0.12$ \\
\hline & T3 & $5.61 \pm 0.12$ & $0.59 \pm 0.05$ & $12.59 \pm 0.21$ & $0.49 \pm 0.09$ & $1.96 \pm 0.07$ & $41.3 \pm 0.14$ \\
\hline & $\mathrm{T} 4$ & $5.59 \pm 0.13$ & $0.49 \pm 0.04$ & $13.78 \pm 0.14^{\mathrm{b}}$ & $0.53 \pm 0.02$ & $2.48 \pm 0.06^{\mathrm{i}}$ & $46.8 \pm 0.09$ \\
\hline & $\mathrm{T} 5$ & $5.41 \pm 0.14$ & $0.49 \pm 0.06$ & $13.78 \pm 0.19^{b}$ & $0.55 \pm 0.04$ & $2.48 \pm 0.03^{\mathrm{i}}$ & $47.2 \pm 0.13$ \\
\hline & T6 & $5.39 \pm 0.05$ & $0.50 \pm 0.01$ & $13.80 \pm 0.14^{b}$ & $0.56 \pm 0.05$ & $2.49 \pm 0.08^{\mathrm{i}}$ & $49.5 \pm 0.24^{\mathrm{d}}$ \\
\hline & $\mathrm{T} 7$ & $5.38 \pm 0.06$ & $0.55 \pm 0.02$ & $12.72 \pm 0.21$ & $0.49 \pm 0.03$ & $1.96 \pm 0.05^{\mathrm{j}}$ & $46.4 \pm 0.17$ \\
\hline
\end{tabular}




\begin{tabular}{l|l|l|l|l|l|l|l}
\hline Storage time & Sample & pH & TA & TSS & BI & $\begin{array}{l}\text { 5-HMF } \\
(\mathbf{m g} / \mathbf{L})\end{array}$ & $\begin{array}{l}\text { Cloud } \\
\text { stability }\end{array}$ \\
\hline & T8 & $5.35 \pm 0.14$ & $0.56 \pm 0.09$ & $12.74 \pm 0.13^{\mathrm{d}}$ & $0.51 \pm 0.01$ & $1.97 \pm 0.02^{\mathrm{j}}$ & $48.2 \pm 0.18$ \\
\hline & $\mathrm{T} 9$ & $5.31 \pm 0.12$ & $0.57 \pm 0.04$ & $12.75 \pm 0.18^{\mathrm{d}}$ & $0.52 \pm 0.02$ & $1.97 \pm 0.07^{\mathrm{j}}$ & $49.7 \pm 0.15^{\mathrm{d}}$
\end{tabular}

Values are expressed as mean $\pm \mathrm{SD}$; different letters in the same column are significant

The acidic juice change significantly the overall $\mathrm{pH}$ of the blend to be more acidic, as confirmed by [43], who found a decrease in $\mathrm{pH}$ from 4.14 to 3.98 of pineapple:carrot: orange blend when the ratio of pineapple decreased from 80 to 50 in blending ratio respectively. During storage, a non-significant decrease in $\mathrm{pH}$ values of all blends decrease with prolonged storage time. The reduction in $\mathrm{pH}$ may be due to the degradation of carbohydrates [44].

The values of titratable acidity for the studied blends ranged from 0.41 (T2 at zero time) to 0.75 (T1 at 14 days of storage), with green-purple $\mathrm{CP}$ having the value $(0.59)$ and pure pineapple juice having a value of 0.68 at zero time without blending (Table 2). With the increasing ratio of each cactus pear juice in the blends, a non-significant change in titratable acidity was observed. However, the pineapple juice incorporation in blends increased the TA of the juice compared to $100 \%$ cactus pear juices. The aforementioned increase may be due to the acidity of pineapple juice which increases the TA in blends.

The decrease in titratable acidity of prepared blends in the current study was confirmed by [45], who noticed a similar trend of pineapple and snack tomato blend after pasteurization and stored for about 30 days at room temperature compared to storage at the refrigerator.

A similar trend for gradual increase with non-significant changes in turbidity and TA and a decrease of $\mathrm{pH}$ for the apple-carrot blend was observed by [19] after storage 21 days.

An important indicator of juice quality is TSS, which is expressed mainly about the free sugars such as sucrose and glucose. The purple CP (T2) showed the highest value of TSS (12.78) in comparison with pure green $\mathrm{CP}$ (11.39) and pineapple juices (11.17), as shown in Table 2. Therefore, the blends prepared from purple $\mathrm{CP}$ and pineapple were higher than green $\mathrm{CP}$ and pineapple in TSS, which may come from hydrolysis of polysaccharides such as cellulose, pectin as well as starch which convert to simple sugars like fructose and glucose [46]. The studied blends exhibited a non-significant $(P \leq 0.05)$ increase in TSS values up to 8 days. Our results are the following [47], who referred to that there is no significant change in TSS values of squash prepared from prickly pear and pineapple. The main stability in $\mathrm{pH}$ and nonsignificant changes in TSS values during storage indicates that no microbial fermentation and microorganisms were found which utilize the sugars for growth and reduce $\mathrm{pH}$ and TSS values [48]. When compared our data with [3] who followed the changes in $\mathrm{pH}$, TSS of three cultivars of pineapple during storage for 28 days at $4^{\circ} \mathrm{C}$ and found deterioration in quality parameters after physical injuries. So, we recommended using the blending technique to preserve the fresh juice of pineapple by blending with cactus pear juices to prolong its shelf-life without any loss or change in $\mathrm{pH}$ and TSS.

Recently, Shamsudin et al. [1] investigated the physicochemical properties of Josapine pineapples, including TSS, $\mathrm{pH}$, and titratable acidity stored at $4^{\circ} \mathrm{C}$ for 25 days. Their results indicated that the physicochemical properties of pineapple were correlated well with the ripening process of the fruit. Elizabeth and Tijesuni [2] investigated the physicochemical composition based on the different proportions of pineapple fruit. Based on their findings, it was revealed that the total soluble solids and $\mathrm{pH}$ increased for all samples, respectively. In addition, Leneveu-Jenvrin et al. [5] evaluated the physicochemical properties of minimallyprocessed pineapple during cold storage and mentioned that the correlation between the storage 
conditions did not significantly vary with the physicochemical properties $(\mathrm{pH}$, titratable acidity, and TSS) of the fruit.

The evaluation of color changes in studied blends (Table 2) during storage was carried out by determining the browning index (BI), which expressed the pure brown color in juice [49]. There is a significant difference in BI at zero time between pure fresh juice, which exhibited 0.24, 0.39, and 0.31 in pineapple, purple CP, and green $\mathrm{CP}$, respectively (Table 2). During storage, the blending of purple cactus pear juices with pineapple yielded higher BI values ranging from 0.46 to 0.56 of T6 after 14 days of storage and at the end, respectively, compared to blending pineapple and green CP (Table 2), which indicate more degree of browning. These results follow Curi et al. [50], who compared the browning degree in a blend of pineapple with persimmon and orange. The browning index increased during storage as an indicator for non-enzymatic browning reactions (Maillard). The high sugar content in both blended juice in our study, either pineapple or both cactus pear, and protein in cactus pear juices in the present media from pineapple juice will make hydrolysis of polysaccharides to give reducing sugar like fructose and sucrose, which react with amino acids or protein from cactus pear juices in Maillard reactions. Also, the rich content of polyphenols reacts with proteins as the main interaction responsible for separation in fruit juices [51]. The non-enzymatic browning in pure cactus pear juices is negligible due to the low concentration of amino acids, especially proline, which react slowly with the sugars like glucose and fructose [52]. Therefore, the browning in studied blends in this study may be due to reactions in pineapple juice.

The quality of fruit juices can be followed up by measuring HMF during thermal treatments and storage as an acceptance indicator from glucose in acidic fruit juice such as pineapple [53]. Several healthy properties were reported for HMF, such as antiproliferative, antioxidant activity exhibited dose-dependent in the range of $(0.8-6.4 \mathrm{mM})$ [54]. The beneficial effects of HMF depend on the consumed concentration (2-30 mg/day) are useful for humans [55]. The formation of HMF can be via caramelization of ascorbic acid or sugars and nonenzymatic browning (Maillard reaction). However, few investigations of the measurement of HMF in fresh juices or processed fruits were carried out, such as Li et al. [56], who mentioned the pathway and role of sugars and amino acids in HMF formation of apple juice concentrate. The studied blends had HMF concentrations ranging from 1.04 to $2.49 \mathrm{mg} / \mathrm{L}$ at $\mathrm{T} 1$ (at zero time) and T6 (at the end of storage), respectively (Table 2), which are less than reported by the International Federation of Fruit Juice Producers as $25 \mathrm{mg} / \mathrm{Kg}$. The established limit of HMF in fruit juices was $5-10 \mathrm{mg} / \mathrm{L}$ as recommended by the International Federation of Fruit Juice Processors (IFFJP) [57]. The data in Table 2 showed an increase in HMF with extending the storage time and an increase in the ratio of cactus pear juices in blends with pineapple juice. Our results confirmed with Al-Diab and Jarkas [58].

During storage for two weeks at the refrigerator, the most significant separation was found in a blend of pineapple with green cactus pear juice at the end of storage (49.7\%) T9. The cloud stability of blended juices prepared from pineapple juice and two cactus pear juices depends on the pineapple and cactus pear juice composition, including; sugars, polyphenols, and proteins (Table 2). The interaction between sugars, phenols, and other ingredients with protein in cactus pear through different mechanisms such as electrostatic mechanisms, which may be responsible for separating two phases in beverages like studied blends in the present investigation. Among the interactions for separation, the first one by complex coacervation or by thermodynamic incompatibility, they were giving increased the protein/polysaccharides 
complexes $[59,60]$. Therefore, more detailed studies are needed to understand the interaction between an ingredient in a blend of pineapple and cactus pear juices.

\subsection{Phytochemical and antiradical activity.}

Phytochemicals such as polyphenols, carotenoids, and flavonoids etc., are the main antioxidants in foods. Phenolics play a vital role in antioxidant activity and health protection as well as provide the color and flavor of fruits and vegetables. The total phenolic concentration was $28.53,59.72$, and $51.46 \mathrm{mg} / 100 \mathrm{~mL}$ of the initial pineapple, purple, and green CP juices, respectively (Table 3). In the first 2 days of storage, the T6 showed the highest concentration of phenolic compounds $(63.94 \mathrm{mg} / 100 \mathrm{~mL})$ compared to a similar blending ratio of green $\mathrm{CP}$ T9, which had $(54.83 \mathrm{mg} / 100 \mathrm{~mL})$. The results showed non-significant changes in total phenolic content after 4 days of storage. However, a small increase was found due to the formation of some compounds reacting with Folin-Ciocalteu and modifying the phenolic content as mentioned by Klimczak et al. [61].

Zulueta et al. [62] evaluate the phenolic content of blends from various fruit juices and milk. Their data ranged from 25.5-99.8 mg GAE/100 ml juice according to the mixed fruit juice with milk. The variation in total phenolic content between blends depends on the maturity and type of fruits, environmental conditions, and storage conditions [63]. At the end of storage no significant loss of total phenolic among the ratios of each blend. However, there is a significant difference $(P \leq 0.05)$ between the two types of blends. The small changes in total phenolic content among each type of blend may be due to the lack of determination using FolinCiocalteu, which reacts with other ingredients other than phenols such as vitamins, minerals, and soluble sugars and proteins [64]. Hence, non-significant changes were observed up to 8 days of storage for all blends. Phenolic compounds had an effective antioxidant activity needed to prevent several diseases such as cancer and different chronic diseases [65].

Table 3. Phytochemicals and antioxidant activity of pineapple juice blended with two cactus pear juice.

\begin{tabular}{|c|c|c|c|c|c|c|}
\hline \multirow[t]{2}{*}{ Storage time } & \multirow[t]{2}{*}{ Sample } & \multirow{2}{*}{$\begin{array}{c}\text { TPC } \\
(\mathrm{mg} / \mathbf{1 0 0 m l})\end{array}$} & \multirow{2}{*}{$\begin{array}{c}\text { TF } \\
(\mathbf{u g} / 100 \mathrm{ml})\end{array}$} & \multirow{2}{*}{$\begin{array}{c}\text { TC } \\
(\mathrm{ug} / 100 \mathrm{ml})\end{array}$} & \multicolumn{2}{|c|}{ AOA } \\
\hline & & & & & $\begin{array}{c}\text { DPPH } \\
\text { EC }_{50} \mu \mathrm{g} / \mathrm{ml}\end{array}$ & $\begin{array}{c}\text { ABTS } \\
\text { uM trolox Eq. }\end{array}$ \\
\hline \multirow[t]{9}{*}{ Day 0} & $\mathrm{~T} 1$ & $28.53 \pm 0.09^{\mathrm{a}}$ & $19.73 \pm 0.09^{\mathrm{a}}$ & $0.17 \pm 0.02^{\mathrm{a}}$ & $4.76 \pm 0.06^{\mathrm{a}}$ & $1.52 \pm 0.08^{\mathrm{a}}$ \\
\hline & $\mathrm{T} 2$ & $59.72 \pm 0.12^{\mathrm{b}}$ & $39.18 \pm 0.02^{\mathrm{b}}$ & $0.53 \pm 0.08^{\mathrm{b}}$ & $3.52 \pm 0.09^{b}$ & $3.96 \pm 0.05^{\mathrm{b}}$ \\
\hline & T3 & $51.46 \pm 0.06^{\mathrm{c}}$ & $30.62 \pm 0.07^{\mathrm{c}}$ & $0.41 \pm 0.06^{\mathrm{c}}$ & $3.98 \pm 0.02^{\mathrm{c}}$ & $2.06 \pm 0.02^{\mathrm{c}}$ \\
\hline & $\mathrm{T} 4$ & $61.23 \pm 0.14^{\mathrm{d}}$ & $42.75 \pm 0.06$ & $0.54 \pm 0.04^{\mathrm{d}}$ & $2.76 \pm 0.03^{\mathrm{d}}$ & $4.25 \pm 0.03^{\mathrm{d}}$ \\
\hline & T5 & $62.47 \pm 0.12^{\mathrm{d}}$ & $43.82 \pm 0.05^{\mathrm{d}}$ & $0.55 \pm 0.03^{\mathrm{d}}$ & $2.49 \pm 0.04^{\mathrm{e}}$ & $4.78 \pm 0.04^{\mathrm{e}}$ \\
\hline & T6 & $63.84 \pm 0.16^{\mathrm{d}}$ & $44.19 \pm 0.02^{\mathrm{d}}$ & $0.56 \pm 0.05$ & $2.35 \pm 0.08^{\mathrm{f}}$ & $4.95 \pm 0.06^{\mathrm{f}}$ \\
\hline & $\mathrm{T} 7$ & $52.63 \pm 0.17^{\mathrm{c}}$ & $38.54 \pm 0.06$ & $0.42 \pm 0.01^{\mathrm{c}}$ & $3.72 \pm 0.01^{\mathrm{g}}$ & $2.87 \pm 0.07^{\mathrm{g}}$ \\
\hline & T8 & $53.72 \pm 0.15$ & $39.72 \pm 0.07$ & $0.43 \pm 0.02^{\mathrm{e}}$ & $3.65 \pm 0.02$ & $2.93 \pm 0.01$ \\
\hline & T9 & $54.83 \pm 0.12^{\mathrm{e}}$ & $40.62 \pm 0.05^{\mathrm{e}}$ & $0.44 \pm 0.07^{\mathrm{e}}$ & $3.49 \pm 0.07$ & $2.98 \pm 0.06$ \\
\hline \multirow[t]{9}{*}{ Day 2} & T1 & $26.43 \pm 0.11$ & $20.72 \pm 0.07$ & $0.13 \pm 0.06$ & $5.72 \pm 0.06$ & $1.51 \pm 0.02$ \\
\hline & $\mathrm{T} 2$ & $57.62 \pm 0.08$ & $40.52 \pm 0.02^{\mathrm{e}}$ & $0.51 \pm 0.05$ & $4.93 \pm 0.03$ & $3.97 \pm 0.08$ \\
\hline & T3 & $50.41 \pm 0.16$ & $31.39 \pm 0.01$ & $0.39 \pm 0.03$ & $5.16 \pm 0.08$ & $2.06 \pm 0.07$ \\
\hline & $\mathrm{T} 4$ & $61.89 \pm 0.18^{\mathrm{d}}$ & $43.15 \pm 0.09$ & $0.53 \pm 0.02$ & $2.58 \pm 0.04$ & $4.29 \pm 0.09$ \\
\hline & T5 & $62.76 \pm 0.17^{\mathrm{d}}$ & $44.29 \pm 0.05^{\mathrm{d}}$ & $0.53 \pm 0.09$ & $2.46 \pm 0.08$ & $4.78 \pm 0.04^{\mathrm{e}}$ \\
\hline & T6 & $63.94 \pm 0.13^{\mathrm{d}}$ & $44.86 \pm 0.07^{\mathrm{d}}$ & $0.54 \pm 0.01^{\mathrm{d}}$ & $2.35 \pm 0.01^{\mathrm{f}}$ & $4.91 \pm 0.03$ \\
\hline & $\mathrm{T} 7$ & $52.78 \pm 0.14$ & $39.25 \pm 0.02$ & $0.41 \pm 0.05^{\mathrm{c}}$ & $3.94 \pm 0.03$ & $2.89 \pm 0.05^{\mathrm{g}}$ \\
\hline & T8 & $54.12 \pm 0.13^{\mathrm{e}}$ & $40.75 \pm 0.06^{\mathrm{e}}$ & $0.42 \pm 0.07^{\mathrm{c}}$ & $3.82 \pm 0.06$ & $2.95 \pm 0.09$ \\
\hline & T9 & $54.83 \pm 0.19^{\mathrm{e}}$ & $41.82 \pm 0.08$ & $0.42 \pm 0.06^{\mathrm{e}}$ & $3.65 \pm 0.04$ & $2.97 \pm 0.08$ \\
\hline \multirow[t]{7}{*}{ Day 4} & $\mathrm{~T} 1$ & $24.52 \pm 0.21$ & $21.53 \pm 0.05$ & $0.11 \pm 0.03$ & $4.82 \pm 0.07$ & $1.49 \pm 0.02$ \\
\hline & $\mathrm{T} 2$ & $56.36 \pm 0.17$ & $40.92 \pm 0.07^{\mathrm{e}}$ & $0.49 \pm 0.02$ & $3.96 \pm 0.02^{\mathrm{c}}$ & $3.92 \pm 0.03$ \\
\hline & $\mathrm{T} 3$ & $49.28 \pm 0.19$ & $32.54 \pm 0.06$ & $0.36 \pm 0.02$ & $4.15 \pm 0.04$ & $2.04 \pm 0.04$ \\
\hline & $\mathrm{T} 4$ & $62.37 \pm 0.24^{\mathrm{d}}$ & $43.97 \pm 0.08$ & $0.51 \pm 0.01$ & $2.38 \pm 0.05^{\mathrm{f}}$ & $4.30 \pm 0.01$ \\
\hline & T5 & $63.14 \pm 0.13^{\mathrm{d}}$ & $44.85 \pm 0.04^{\mathrm{d}}$ & $0.51 \pm 0.06$ & $2.29 \pm 0.07$ & $4.79 \pm 0.06^{\mathrm{e}}$ \\
\hline & T6 & $64.05 \pm 0.14$ & $45.17 \pm 0.01^{\mathrm{d}}$ & $0.52 \pm 0.05^{\mathrm{b}}$ & $2.17 \pm 0.03$ & $4.92 \pm 0.02$ \\
\hline & $\mathrm{T} 7$ & $53.12 \pm 0.18$ & $40.65 \pm 0.09^{\mathrm{e}}$ & $0.39 \pm 0.04$ & $3.85 \pm 0.07$ & $2.90 \pm 0.04^{\mathrm{g}}$ \\
\hline
\end{tabular}




\begin{tabular}{|c|c|c|c|c|c|c|}
\hline \multirow[t]{2}{*}{ Storage time } & \multirow[t]{2}{*}{ Sample } & \multirow{2}{*}{$\begin{array}{c}\text { TPC } \\
(\mathbf{m g} / \mathbf{1 0 0 m l})\end{array}$} & \multirow{2}{*}{$\begin{array}{c}\text { TF } \\
(\mathbf{u g} / 100 \mathrm{ml})\end{array}$} & \multirow{2}{*}{$\begin{array}{c}\text { TC } \\
(\mathrm{ug} / 100 \mathrm{ml})\end{array}$} & \multicolumn{2}{|c|}{ AOA } \\
\hline & & & & & $\begin{array}{c}\text { DPPH } \\
\text { EC }_{50} \mu \mathrm{g} / \mathrm{ml}\end{array}$ & $\begin{array}{c}\text { ABTS } \\
\text { uM trolox Eq. }\end{array}$ \\
\hline & T8 & $54.87 \pm 0.12^{\mathrm{e}}$ & $41.29 \pm 0.05$ & $0.39 \pm 0.06$ & $3.76 \pm 0.02^{\mathrm{g}}$ & $2.96 \pm 0.09$ \\
\hline & T9 & $55.03 \pm 0.15^{\mathrm{f}}$ & $42.37 \pm 0.04$ & $0.40 \pm 0.09$ & $3.59 \pm 0.08$ & $2.98 \pm 0.02$ \\
\hline \multirow[t]{9}{*}{ Day 8} & $\mathrm{~T} 1$ & $22.39 \pm 0.19$ & $20.95 \pm 0.03$ & $0.09 \pm 0.05$ & $5.16 \pm 0.09$ & $1.43 \pm 0.08$ \\
\hline & $\mathrm{T} 2$ & $54.26 \pm 0.12^{\mathrm{e}}$ & $39.86 \pm 0.07$ & $0.47 \pm 0.07$ & $3.97 \pm 0.06^{\mathrm{c}}$ & $3.91 \pm 0.01$ \\
\hline & T3 & $47.31 \pm 0.21$ & $31.59 \pm 0.06$ & $0.35 \pm 0.08$ & $4.18 \pm 0.04$ & $2.02 \pm 0.03$ \\
\hline & $\mathrm{T} 4$ & $62.78 \pm 0.16^{\mathrm{d}}$ & $44.26 \pm 0.04^{\mathrm{d}}$ & $0.49 \pm 0.03$ & $2.38 \pm 0.06^{\mathrm{f}}$ & $4.31 \pm 0.07$ \\
\hline & T5 & $64.19 \pm 0.18$ & $45.19 \pm 0.01^{\mathrm{d}}$ & $0.50 \pm 0.02$ & $2.26 \pm 0.03$ & $4.80 \pm 0.06$ \\
\hline & T6 & $65.07 \pm 0.19$ & $46.38 \pm 0.05^{\mathrm{f}}$ & $0.50 \pm 0.01$ & $2.15 \pm 0.04$ & $4.93 \pm 0.05$ \\
\hline & T7 & $53.92 \pm 0.17$ & $41.76 \pm 0.02$ & $0.37 \pm 0.04$ & $3.87 \pm 0.02^{\mathrm{c}}$ & $2.86 \pm 0.04$ \\
\hline & T8 & $55.13 \pm 0.13$ & $42.35 \pm 0.07$ & $0.38 \pm 0.05$ & $3.75 \pm 0.09^{\mathrm{g}}$ & $2.87 \pm 0.02$ \\
\hline & T9 & $55.64 \pm 0.15^{\mathrm{f}}$ & $43.76 \pm 0.09$ & $0.38 \pm 0.02$ & $3.58 \pm 0.01$ & $2.89 \pm 0.01^{\mathrm{g}}$ \\
\hline \multirow[t]{9}{*}{ Day 14} & T1 & $23.13 \pm 0.12$ & $20.59 \pm 0.08$ & $0.05 \pm 0.03$ & $5.24 \pm 0.05$ & $1.39 \pm 0.06$ \\
\hline & $\mathrm{T} 2$ & $53.48 \pm 0.17$ & $39.82 \pm 0.03$ & $0.41 \pm 0.06^{\mathrm{c}}$ & $4.18 \pm 0.07$ & $3.86 \pm 0.05$ \\
\hline & T3 & $45.62 \pm 0.14$ & $30.57 \pm 0.02$ & $0.32 \pm 0.03$ & $4.79 \pm 0.02$ & $2.01 \pm 0.04$ \\
\hline & $\mathrm{T} 4$ & $63.14 \pm 0.13$ & $44.13 \pm 0.04$ & $0.41 \pm 0.02^{\mathrm{c}}$ & $2.34 \pm 0.06^{\mathrm{f}}$ & $4.29 \pm 0.03$ \\
\hline & T5 & $64.78 \pm 0.11$ & $45.92 \pm 0.02^{\mathrm{d}}$ & $0.41 \pm 0.01^{\mathrm{c}}$ & $2.25 \pm 0.04$ & $4.78 \pm 0.08^{\mathrm{e}}$ \\
\hline & T6 & $65.92 \pm 0.19$ & $46.73 \pm 0.09^{\mathrm{f}}$ & $0.42 \pm 0.04^{\mathrm{e}}$ & $2.13 \pm 0.02$ & $4.81 \pm 0.04^{\mathrm{e}}$ \\
\hline & $\mathrm{T} 7$ & $54.17 \pm 0.14$ & $41.82 \pm 0.04$ & $0.53 \pm 0.03^{b}$ & $3.89 \pm 0.06$ & $2.83 \pm 0.05$ \\
\hline & $\mathrm{T} 8$ & $55.69 \pm 0.16^{\mathrm{f}}$ & $42.59 \pm 0.06$ & $0.36 \pm 0.01$ & $3.82 \pm 0.04$ & $2.85 \pm 0.02$ \\
\hline & T9 & $55.83 \pm 0.15^{\mathrm{f}}$ & $43.54 \pm 0.03^{\mathrm{d}}$ & $0.35 \pm 0.06$ & $3.81 \pm 0.05$ & $2.86 \pm 0.07$ \\
\hline
\end{tabular}

Therefore, the increase in phenolic content is desirable for human health, which can be obtained by fruit juice blending, such as in the current study. Also, the increase in phenolic content is preferred for consumers and commercial use.

After eight days of storage, T6 showed the value of the highest of total flavonoids (46.38 ug/100 mL) compared to T1, which had the least value $(20.59 \mathrm{ug} / 100 \mathrm{~mL})$ at the end of storage (Table 3). The health benefits of flavonoids depend on the chemical structure; the low intestinal absorption due to the presence of flavonoid rutinosides [66]. To improve the efficiency of flavonoids functional properties, several trials had carried out to remove the sugar moiety via hydrolysis. Another example the breast cancer treatment related to kaempferol, quercetin, and isorhamnetin, in cactus fruit [67]. Cactus pear fruits with different colors are rich sources of phenolic compounds formed through phenylpropanoid and shikimic acid pathways [68]. There are two forms of phenolic compounds, either bound or free form. The first form is present after transporting polyphenols to the cell wall and conjugation [69]. The increase of phenolic compounds in cactus pear during storage was reported by Zafra-Rojas et al. [70] due to the formation of hydroxyl groups which may be added to aromatic rings in phenolic compounds leading to an increase in phenolic concentration. Another theory for increase in phenolic content in mild thermal treated blends in the present study is due to the release of polyphenolic in acoustic activity, which leads to releases the bound phenolics from plant cells to the juice $[71,72]$. The high concentrations of phenolic and flavonoids content in purple $\mathrm{CP}$ blends compared with green $\mathrm{CP}$ are supported by Abdel-Hameed et al. [73], who studied the phytochemicals of two prickly pear peel and pulp in KSA. An opposite data was reported by [74]. The variation in results for phenolic content in previous studies may be due to the lack of methodology- routine assay- which depends on Folin-Ciocalteu, which react with non-phenolic compounds [75]. The low concentration of carotenoids in pineapple is 0.17 $\mathrm{ug} / 100 \mathrm{~mL}$ compared to both cactus pear juice representing 0.53 and $0.41 \mathrm{ug} / 100 \mathrm{~mL}$ in purple and green $\mathrm{CP}$, respectively (Table 3) confirmed by Stinco et al. [76].

Steingass et al. [77] identified the genuine carotenoids in pineapple as (all-E)- $\beta$ carotene and (all-E)-lutein and reported that the total content of carotenoids was higher in yellow cultivars compared to green cultivars to be in the range of $359-432 \mu \mathrm{g} / 100 \mathrm{~g}$ of FW. 
Total carotenoid content assessed and varied widely among blends of pineapple with purple $\mathrm{CP}$ compared to pineapple and green $\mathrm{CP}$. The values ranged from $0.56 \pm 0.05$ to $0.35 \pm 0.06$ $\mathrm{ug} / 100 \mathrm{~mL}$ in $\mathrm{T} 6$ at zero time and $\mathrm{T} 9$ at the end of storage, respectively (Table 3). This significant variation comes from several factors, such as the type of fruits and blending ratios, and storage time. Our data is the following [78].

During the storage of fruit juice and its blends, the chemical reactions affect the shelflife and cause deterioration in sensory properties like odor, color, and antioxidant activity. There are several antioxidant activity mechanisms that make it difficult to determine the activity using a single method. Therefore, it is important to determine the antioxidant activity by more than one method. In the present study, the determination of antiradical activity was carried out using DPPH and ABST methods, and the obtained results are given in Table 3 . The applied methods revealed an excellent antioxidant activity which is in agreement with [79]. The mechanisms for cactus pear juices antioxidant described to be reducing agent [80]; chelating metals [81], and quenching single oxygen [82].

The blends of pineapple with purple CP showed a higher total antioxidant activity than pineapple with green $\mathrm{CP}$ juice (Table 3). The two methods of assays by DPPH and ABST showed a similar trend. The obtained data are confirmed by [83], who suggested using prickly pear as effective antigenotoxic according to the structure of the phytochemical. The low values of $\mathrm{EC}_{50}$ as an indicator for antioxidant activity with prolonged storage time and increase the ratio of cactus pear juices in blends (Table 3) compared to control samples. Similar data are reported by Nadeem et al. [72] in a blend of grape-carrot as well as by Zafra-Rojas et al. [70] after treating cactus pear juice with ultrasound.

Recently Gomez-Maqueoa et al. [84] found that pisidic acid is the most abundant bioactive compound in prickly pear with a concentration of 83.3 to $91.7 \%$ in Mexican and Spanish cultivars, respectively, and exhibit high stability even after high hydrostatic pressure treatment to increase the extraction of bioactive compounds and consequently improve antiinflammatory activities and antioxidant properties. There is a good correlation between the antioxidant activity of pineapple and cactus pear and their bioactive components like carotenoids and flavonoids. Antioxidant activity of cactus pear juice correlated well with phenolics, especially isorhamnetin-3-O-glucoside, isorhamnetin-3-O-rutinoside, and Kaempferol-3-O-rutinoside, and betalains can be considered as the powerful antioxidant compounds in cactus pear juices [85, 86]. The increase in antioxidant activity at the end of storage is in agreement with Zulueta [87], who reported an increase in antioxidant activity of blend from orange juice with milk. Also, the increase in antioxidant activity was confirmed by [88], who found an increase of about 3-folds in antioxidant activity of prickly pear juice after fermentation for $36 \mathrm{hr}$. with lactic acid bacteria compared to control samples.

It is important to note that the studied juice is rich in sugars, amino acids, and ascorbic acid, suitable conditions for the Maillard reaction. Ascorbic acid plays a major role in protecting betacyanins from degradation during shelf life and thermal processing [89]. On the other hand, ascorbic acid is available for degradation during non-enzymatic browning reactions [90]. Maillard reactions products contribute potent antioxidant activity and antimicrobial activity depending on the degree of browning [91]. The results of [92] mentioned the ability of Maillard reaction products to increase the shelf life of foods by reducing the oxidation and growth of microorganisms. Therefore, studies concerning non-enzymatic browning in pineapple and cactus pear products are still not sufficient. 


\subsection{Microbiological evaluation.}

The studied blends of pineapple and two cactus pear juices were safe during all storage time, except the blends contain a higher ratio of pineapple T4 and T7 compared to cactus pear juice (Table 4). All blends exhibited safe analysis from a microbiological view at the beginning of storage, which had no growth for bacteria, yeast, and molds. Our results were confirmed with Joy and Rani [93], who evaluated the antimicrobial effect of pineapple and aloe jam. All blends ratios for yeast and mold count during storage for two weeks at the refrigerator were acceptable. Therefore, the blends were safe from the yeast and molds view until 14 days (Table 4). The acidic juice like pineapple, which had a pH of approximately (3.45) could be considered protected against deterioration by microbial spoilage. So, the blends during storage depend on the ratio of pineapple juice.

Table 4. Total plate count and yeast and molds count $(\mathrm{Cfu} / \mathrm{ml})$ of pineapple juice with two cactus pear juice at various ratios during storage.

\begin{tabular}{|c|c|c|c|c|c|}
\hline Treatment & Zero day & Day 2 & Day 4 & Day 8 & Day 14 \\
\hline \multicolumn{6}{|c|}{ Total Plate Count } \\
\hline $\mathrm{T} 1$ & Nil & Nil & $0.16 \times 10^{2}$ & $0.35 \times 10^{2}$ & $0.98 \times 10^{2}$ \\
\hline $\mathrm{T} 2$ & Nil & Nil & $0.12 \times 10^{2}$ & $0.27 \times 10^{2}$ & $0.45 \times 10^{2}$ \\
\hline $\mathrm{T} 3$ & Nil & Nil & $0.19 \times 10^{2}$ & $0.26 \times 10^{2}$ & $0.76 \times 10^{2}$ \\
\hline $\mathrm{T} 4$ & Nil & Nil & $0.19 \times 10^{2}$ & $0.59 \times 10^{2}$ & $0.85 \times 10^{2}$ \\
\hline T5 & Nil & Nil & $0.13 \times 10^{2}$ & $0.17 \times 10^{2}$ & $0.43 \times 10^{2}$ \\
\hline T6 & Nil & Nil & $0.12 \times 10^{2}$ & $0.12 \times 10^{2}$ & $0.26 \times 10^{2}$ \\
\hline $\mathrm{T} 7$ & Nil & Nil & $0.21 \times 10^{2}$ & $0.25 \times 10^{2}$ & $0.68 \times 10^{2}$ \\
\hline $\mathrm{T} 8$ & Nil & Nil & $0.19 \times 10^{2}$ & $0.13 \times 10^{2}$ & $0.47 \times 10^{2}$ \\
\hline T9 & Nil & Nil & $0.17 \times 10^{2}$ & $0.12 \times 10^{2}$ & $0.32 \times 10^{2}$ \\
\hline \multicolumn{6}{|c|}{ Yeast and Molds Count } \\
\hline $\mathrm{T} 1$ & Nil & Nil & $0.12 \times 10^{1}$ & $0.28 \times 10^{1}$ & $0.67 \times 10^{1}$ \\
\hline $\mathrm{T} 2$ & Nil & Nil & $0.13 \times 10^{1}$ & $0.43 \times 10^{1}$ & $0.49 \times 10^{1}$ \\
\hline $\mathrm{T} 3$ & Nil & Nil & $0.13 \times 10^{1}$ & $0.37 \times 10^{1}$ & $0.65 \times 10^{1}$ \\
\hline $\mathrm{T} 4$ & Nil & Nil & Nil & $0.25 \times 10^{1}$ & $0.48 \times 10^{1}$ \\
\hline T5 & Nil & Nil & Nil & $0.13 \times 10^{1}$ & $0.31 \times 10^{1}$ \\
\hline T6 & Nil & Nil & Nil & $0.12 \times 10^{1}$ & $0.25 \times 10^{1}$ \\
\hline $\mathrm{T} 7$ & Nil & Nil & Nil & $0.27 \times 10^{1}$ & $0.92 \times 10^{1}$ \\
\hline T8 & Nil & Nil & Nil & $0.13 \times 10^{1}$ & $0.74 \times 10^{1}$ \\
\hline T9 & Nil & Nil & Nil & $0.13 \times 10^{1}$ & $0.61 \times 10^{1}$ \\
\hline
\end{tabular}

\subsection{Organoleptic evaluation.}

After preparing blends at zero time, we found no significant difference $(P \leq 0.05)$ in sensory scores of all blends as the sweet taste of pineapple and cactus pear juices. T6 blend amongst all blends was found to be the most preferred one. Therefore, we follow up the sensory evaluation and volatile compounds using GC-MS of this blend during storage. The panelists were asked to evaluate the following characteristics color, appearance, taste, flavor, consistency, and overall acceptability, and their scores are given in Table 5. The results showed no significant difference in the studied attributes during storage time for the blend of pineapple (1): purple cactus pear juice (3). According to Rahman et al. [94], our findings are recorded the sensory evaluation of pineapple, mango, and aloe vera jam.

The most acceptable blend in the present investigation reached two weeks at refrigerator is less than mentioned by Islam et al. [37], who found that the accessibility of its blend was about three weeks.

The high TSS value in purple CP with pineapple may explain the sweet taste of these blends compared to green $\mathrm{CP}$ with pineapple.

Table 5. Sensory analysis of pineapple and purple cactus pear blend (1:3) during storage 


\begin{tabular}{l|l|l|l|l|l|l}
\hline Samples & Color & Appearance & Taste & Flavor & Consistency & OAA \\
\hline Day zero & $8.9 \pm 0.19^{\mathrm{a}}$ & $8.8 \pm 0.31^{\mathrm{a}}$ & $8.7 \pm 0.11^{\mathrm{a}}$ & $8.7 \pm 0.14^{\mathrm{a}}$ & $8.6 \pm 0.11^{\mathrm{a}}$ & $8.7 \pm 0.16^{\mathrm{a}}$ \\
\hline Day 2 & $8.7 \pm 0.22^{\mathrm{a}}$ & $8.8 \pm 0.37^{\mathrm{a}}$ & $8.7 \pm 0.09^{\mathrm{a}}$ & $8.7 \pm 0.12^{\mathrm{a}}$ & $8.6 \pm 0.14^{\mathrm{a}}$ & $8.7 \pm 0.17^{\mathrm{a}}$ \\
\hline Day 4 & $8.6 \pm 0.14^{\mathrm{a}}$ & $8.6 \pm 0.25^{\mathrm{b}}$ & $8.6 \pm 0.17^{\mathrm{a}}$ & $8.5 \pm 0.19^{\mathrm{b}}$ & $8.5 \pm 0.12^{\mathrm{b}}$ & $8.6 \pm 0.12^{\mathrm{b}}$ \\
\hline Day 8 & $8.5 \pm 0.13^{\mathrm{b}}$ & $8.6 \pm 0.16^{\mathrm{b}}$ & $8.5 \pm 0.13^{\mathrm{b}}$ & $8.5 \pm 0.15^{\mathrm{b}}$ & $8.5 \pm 0.09^{\mathrm{b}}$ & $8.6 \pm 0.13^{\mathrm{b}}$ \\
\hline Day 14 & $8.4 \pm 0.17^{\mathrm{b}}$ & $8.5 \pm 0.12^{\mathrm{b}}$ & $8.5 \pm 0.14^{\mathrm{b}}$ & $8.4 \pm 0.12^{\mathrm{b}}$ & $8.4 \pm 0.16^{\mathrm{b}}$ & $8.5 \pm 0.15^{\mathrm{b}}$ \\
\hline LSD 0.5 & $\mathbf{0 . 6 5}$ & $\mathbf{0 . 5 7}$ & $\mathbf{0 . 4 9}$ & $\mathbf{0 . 3 8}$ & $\mathbf{0 . 7 2}$ & $\mathbf{0 . 6 8}$
\end{tabular}

$\mathrm{OA}=$ overall acceptability, the same letters within the same column are not significant

\subsection{Volatile compounds profile.}

The flavor is the most important sensory attribute that determines consumers' fruit juice preference and acceptability [95]. The extraction of volatile compounds in pure pineapple, purple $\mathrm{CP}$, and the most acceptable blend $\mathrm{T} 6$ from them with a ratio of (1 pineapple: 3 purple $\mathrm{CP}$ ) carried out using SPME and subjected to analysis by GC-MS, and the summarized data are given in Table 6 .

In a total of forty-none volatile compounds with their available organoleptic properties were identified and given in Table 6. Numerically, 19 esters prevailed, 8 aldehydes, 6 terpenes, 4 lactones, 2 alcohols, 1 acid, and 1 furanone. The classification of the identified volatile compounds into esters, alcohols, acids, terpenes, and lactones agrees with [21, 97]. The main volatile esters in fresh, pure pineapple juice were esters, especially ethyl acetate (pineapple odor); methyl 2-methyl butanoate, and ethyl butanoate, which represent (13.11\%); (9.32\%) and $(8.38 \%)$ respectively (Table 6$)$. The second common volatile compounds were terpenes and alcohols, which had significant concentrations; linalool (10.42\%) 1-hexanol (10.27\%). The obtained data in accordance with [95] who reported that the main volatile compounds in pineapple juice were esters and terpenes. However, they mentioned another ester that differed from those reported in this study. This variation may be due to the method of extraction and degree of maturation for fruit used in processing [98].

The previous study carried out by Ikram et al. [99] mentioned that the main volatile compounds in pineapple juice were esters like methyl hexanoate and methyl-2methyl butanoate which confirmd the obtained results in the present study.

The analysis of volatile compounds revealed that four lactones had been identified, namely $\gamma$-hexalactone; $\gamma$-octalactone, $\delta$-octalactone, and $\gamma$-nonalactone with concentrations of $0.09 \%, 1.72 \%, 0.67 \%$, and $0.86 \%$, respectively (Table 6 ). These data may be due to the used fresh fruits in preparation of pineapple juice and differed from [100], who detected only one lactone in pineapple after freezing and referred to that freezing caused a reduction in volatile of pineapple due to internal defects. Data in (Table 6) showed only one furanone compound, 4-methoxy-2,5-dimethyl-3(2H)- furanone, with a significant concentration reach of $(8.33 \%)$. The obtained results are confirmed by [101, 102], who mentioned that 4-methoxy-2,5dimethyl-3(2H)- furanone- caramel-like odor- and lactones are responsible for the sweet and fruity notes of ripe pineapple fruits.

The analysis of fresh, pure purple cactus pear juice showed that; the major volatile compounds were alcohols followed by aldehydes. 1-Hexanol had the highest concentration $(12.41 \%)$, followed by hexanal $(10.86 \%)$ (Table 6). Among the most common terpene in this study is d-limonene (lemon), which represents $(7.82 \%)$.

The obtaned data in accordance with Andreu-Coll et al. [97] who found that the main volatile compounds in fruit pulp of six spanish cultivars of Opuntia ficus-indica were alcohols and aldehydes as well as d-limonene. 
Table 6. Volatile compounds of fresh pineapple and purple CP juices as well as fresh and stored for two weeks (T6).

\begin{tabular}{|c|c|c|c|c|c|c|c|}
\hline \multirow[t]{2}{*}{ Volatile compounds } & \multirow[t]{2}{*}{$\mathbf{R I}^{\mathbf{a}}$} & \multirow[t]{2}{*}{ Pineapple } & \multirow[t]{2}{*}{ Purple CP } & \multicolumn{2}{|l|}{ T6 } & \multirow[t]{2}{*}{ Classification } & \multirow[t]{2}{*}{ Organoleptic $^{c}$} \\
\hline & & & & Fresh & Stored & & \\
\hline Ethanol & 619 & 3.49 & 3.98 & 9.56 & 7.12 & Alcohol & Ethanol, alcohol \\
\hline Methyl acetate & 627 & 2.85 & 2.56 & 4.98 & 6.27 & Ester & \\
\hline Ethyl acetate & 653 & 13.11 & 4.37 & 12.46 & 8.52 & Ester & paint, fruity \\
\hline Methyl propanoate & 664 & 0.62 & 1.02 & 0.89 & 1.06 & Ester & \\
\hline $\begin{array}{l}\text { Methyl } \\
\text { methylpropanoate }\end{array}$ & 689 & 0.21 & 1.76 & 1.56 & 1.39 & Ester & \\
\hline Methyl 2-propenoate & 693 & 0.02 & 1.45 & 1.23 & 1.07 & Ester & \\
\hline Ethyl 2-propenoate & 698 & 0.39 & 0.09 & 0.18 & 0.12 & Ester & \\
\hline Ethyl propanoate & 705 & 1.39 & 1.18 & 1.24 & 1.08 & Ester & fruity \\
\hline n-Propyl acetate & 718 & 2.77 & n.d & 1.59 & 1.03 & Ester & \\
\hline Methyl butanoate & 729 & 3.18 & 2.67 & 2.89 & 2.17 & Ester & fruity, sweet \\
\hline $\begin{array}{ll}\text { Ethyl } & 2- \\
\text { methylpropanoate }\end{array}$ & 763 & 0.81 & 3.11 & 2.16 & 1.46 & Ester & \\
\hline Hexanal & 776 & 0.33 & 10.86 & 0.53 & 0.07 & Aldehyde & Green \\
\hline $\begin{array}{l}\text { Methyl } \\
\text { methylbutanoate }\end{array}$ & 782 & 9.32 & 0.32 & 0.39 & 1.35 & Ester & $\begin{array}{l}\text { green, fruity, } \\
\text { pear }\end{array}$ \\
\hline $\begin{array}{l}\text { Methyl 3- } \\
\text { methylbutanoate }\end{array}$ & 789 & 0.24 & n.d & 0.01 & 0.02 & Ester & $\begin{array}{l}\text { fruity, apple, } \\
\text { pineapple }\end{array}$ \\
\hline Furfural & 831 & 1.34 & 2.85 & 2.84 & 4.96 & Aldehyde & Sweet, caramel \\
\hline Ethyl butanoate & 847 & 8.38 & 4.29 & 7.26 & 4.16 & Ester & Fruity, Apple \\
\hline Methyl pentanoate & 851 & 0.65 & 4.38 & 0.30 & 2.58 & Ester & \\
\hline 1-Hexanol & 863 & 10.27 & 12.41 & 12.46 & 6.34 & Alcohol & Green, fruity \\
\hline Heptanal & 884 & 0.19 & 3.65 & 0.40 & 4.69 & Aldehyde & $\begin{array}{l}\begin{array}{l}\text { Fruity, oily- } \\
\text { greasy }\end{array} \\
\end{array}$ \\
\hline Methyl hexanoate & 916 & 0.49 & 2.76 & 1.96 & 1.37 & Ester & apple peel, fruity \\
\hline $\begin{array}{l}\text { Dimethyl } \\
\text { propanedioate }\end{array}$ & 928 & 0.10 & 0.00 & 0.57 & 0.38 & Ester & \\
\hline Benzaldehyde & 976 & 0.97 & 6.92 & 7.62 & 10.93 & Aldehyde & $\begin{array}{l}\text { Bitter almond, } \\
\text { walnut }\end{array}$ \\
\hline Hexanoic acid & 978 & 0.17 & 1.34 & 0.61 & 0.19 & Acid & \\
\hline$\alpha$-Pinene & 985 & 0.51 & 0.11 & 0.07 & 0.30 & Terpene & Piney \\
\hline$\beta$-Pinene & 993 & 0.37 & 0.92 & 0.94 & 0.95 & Terpene & Piney \\
\hline Myrecene & 1009 & 0.10 & 1.05 & 0.61 & 1.34 & Terpene & $\begin{array}{l}\text { Lemon, } \\
\text { Grapefruit }\end{array}$ \\
\hline Octanal & 1026 & 0.98 & n.d & 0.45 & 4.52 & Aldehyde & Fruity, Citrusy \\
\hline Octanal & 1031 & 0.91 & 1.28 & 0.74 & 3.16 & Aldehyde & citrus, orange \\
\hline Ethyl (Z)-3-hexenoate & 1035 & 1.57 & 2.71 & 0.31 & 0.07 & Ester & \\
\hline D-Limonene & 1037 & 1.79 & 7.82 & 2.16 & 2.46 & Terpene & Lemon, Minty \\
\hline$\gamma$-Hexalactone & 1078 & 0.09 & 0.65 & 0.38 & 0.46 & Lactone & \\
\hline $\begin{array}{l}\text { 4-Methoxy-2,5- } \\
\text { dimethyl-3(2H)- } \\
\text { furanone }\end{array}$ & 1083 & 8.15 & 0.24 & 0.61 & 0.59 & Furanone & $\begin{array}{l}\text { Caramel-like, } \\
\text { sweet }\end{array}$ \\
\hline Linalool & 1168 & 10.42 & 5.47 & 7.46 & 9.25 & Terpene & Fruity \\
\hline Ethyl octanoate & 1197 & 0.12 & 0.13 & 0.33 & 0.14 & Ester & \\
\hline Decanal & 1209 & 0.10 & 0.38 & 0.13 & 2.17 & Aldehyde & Citrus, orange \\
\hline 1-Terpinen-4-ol & 1219 & 4.26 & 1.29 & 7.26 & 2.47 & Terpene & \\
\hline Nonanal & 1224 & 2.63 & 1.48 & 0.07 & 1.34 & Aldehyde & $\begin{array}{l}\text { Citrus, } \\
\text { cucumber }\end{array}$ \\
\hline Ethyl 2-phenylacetate & 1249 & 0.99 & n.d & 1.17 & 0.13 & Ester & \\
\hline$\gamma$ - Octalactone & 1261 & 1.72 & 1.26 & 1.26 & 0.56 & Lactone & Coconut \\
\hline$\delta$-Octalactone & 1287 & 0.67 & 0.49 & 0.57 & 0.18 & Lactone & Sweet \\
\hline$\gamma$-Nonalactone & 1369 & 0.86 & 2.48 & 1.38 & 1.23 & Lactone & Sweet, peach \\
\hline
\end{tabular}

D-limonene plays a domestic role in the flavor of various citrus fruits and their juices and contributes to food flavor. Therefore, cactus pear fruits and juice consumption, either pure or in blends, improves the biological activity due to antioxidant and antimicrobial activity [103].

Other important aldehyde and terpene were benzaldehyde (almond-like odor) and linalool (odor threshold $=6 \mathrm{ppb}$ ) which had concentrations of $6.92 \%$ and $5.47 \%$, respectively 
(Table 6). Arena et al. [104] mentioned that linalool is a major volatile compound in fruits of prickly pear with a concentration higher than mentioned in our study, and [105] reported that linalool is an important aroma-volatile compound in orange essence oil.

Overall, the fresh blend T6 was characterized by significant concentrations of esters and alcohols compared to single pure juice from pineapple or purple cactus pear juice. Compared with the sorted blend, there is no significant decrease in characteristics of esters (ethyl acetate and ethyl 2-methylpropanoate) and alcohols (1-hexanol). The stored blend of pineapple and purple CP (1:3) exhibited a remarkable increase in aldehydes, especially benzaldehyde, to be $10.93 \%$ compared to the fresh blend, which had $7.62 \%$ (Table 6). The obtained results were confirmed by Karabagias et al. [42], who found that the stored blend prepared from prickly pear and blossom honey reached about three months.

During storage, a significant increase in furfural concentration was observed from $2.85 \%$ to $4.96 \%$ (Table 6 ). This note follows previous studies of $[106,107]$, who mentioned that furfural formed from ascorbic acid degradation and could be used as an indicator for longterm storage in orange juice. On contrast a non-significant decline in 4-methoxy-2,5-dimethyl$3(2 \mathrm{H})$ - furanone in stored blend $(0.61 \%)$ compared to fresh blend $(0.59 \%)$ was occurred. Our data is in good agreement with Steingass et al. [108], who followed the changes in volatile compounds of pineapple under acceleration of light for 16 weeks. The significant concentrations of volatile compounds in the studied blend T6 like esters (ethyl acetate) and alcohol (1-hexanol) which correlated well with antimicrobial activity, may explain the high stability during storage from the microbiological view Adiani et al. [109]. The changes of volatile compounds in pineapple juice, either pure or in blends, play a significant role in the quality control of pineapple products [110].

The remarkable concentrations of d-limonene and linalool, which had active aroma compounds in different plants with biological activities besides phenolic content and flavonoids, may explain the antimicrobiological activity in the stored blend [111, 112]. Also, the effective antimicrobial activity of the prepared blends may be due to the presence of flavonoids from pineapple and cactus pear juices which act by various mechanisms as antimicrobial, and their efficiency increase in the presence of d-limonene [103]. The increase of aldehyde-like hexanal agrees with Hashizume et al. [113], who mentioned a significant increase of hexanal in apple juice subjected to fluorescent light during storage.

Linalool is responsible for the pleasant flavor of different fruits and essential oils and is found in a pineapple at various ripening stages [114]. The blend prepared from pineapple and cactus pear juice by Saenz [115] had good results despite the adverse effect of pineapple on the characteristic aroma of pear juice, and they suggest using citric acid to improve this blend.

A slight reduction in lactones of T6 was observed after storage, which correlated with the sweet taste in sensory evaluation (Table 5). The formation of lactones depends on the temperature of storage which regulates the acyl-CoA oxidases as mentioned by Xi et al. [116] in peach and suggested by Steingass et al. [117] to apply in pineapple.

\section{Conclusions}

The results in this study demonstrated that blends of pineapple and cactus pear juices improved the physicochemical properties, including phytochemical contents, antiradical and antimicrobial activity during storage for two weeks at the refrigerator. We recommended using a blending technique for preserving the fresh juice of pineapple by blending with cactus pear 
juices to prolong its shelf-life without any loss or change in pH and TSS. The selected blend T6 may be useful for human health due to the high content of phytochemicals, acceptability, and excellent antiradical and antimicrobial activities. The economic evaluation of this blend is in need to apply at an industrial scale. More detailed studies are needed to understand the interaction between an ingredient in a blend of pineapple and cactus pear juices. Also, studies concerning Maillard reactions in cactus pear blends with pineapple juice are still not sufficient to explore the changes in antioxidant activity during storage.

\section{Funding}

This research received no external funding.

\section{Acknowledgments}

This research has no acknowledgment.

\section{Conflicts of Interest}

The authors declare no conflict of interest.

\section{References}

1. Shamsudin, R.; Zulkifli, N.; Kamarul, Z. Quality attributes of fresh pineapple-mango juice blend during storage. Inter. Food Rese. J. 2020, 27, 141-149.

2. Adelakun, O.E.; Taiwo, O.T. Physico-chemical and Organoleptic Evaluation of Drink Produced from Pineapple (Ananas comosus) and Tigernut (Cyperus esculentus). Asian Food Science Journal 2020, 14, 1-8, https://doi.org/10.9734/afsj/2020/v14i230123.

3. Dolhaji, N.H.; Muhamad, I.I.; Ya'Akub, H.; Abd Aziz, A.J.M.J.o.F.; Sciences, A. Evaluation of chilling injury and internal browning condition on quality attributes, phenolic content, and antioxidant capacity during sub-optimal cold storage of Malaysian cultivar pineapples. J. Fundamental and Applied Sci. 2019, 14, 456461, https://doi.org/10.11113/mjfas.v14n4.1072.

4. Rinaldi, M.; Littardi, P.; Ganino, T.; Aldini, A.; Rodolfi, M.; Barbanti, D.; Chiavaro, E. Comparison of physical, microstructural, antioxidant and enzymatic properties of pineapple cubes treated with conventional heating, ohmic heating and high-pressure processing. LWT 2020, 134, https://doi.org/10.1016/j.lwt.2020.110207.

5. Leneveu-Jenvrin, C.; Quentin, B.; Assemat, S.; Remize, F. Maintaining Physicochemical, Microbiological, and Sensory Quality of Pineapple Juice (Ananas comosus, Var. 'Queen Victoria') through Mild Heat Treatment. Processes 2020, 8, https://doi.org/10.3390/pr8091186.

6. Romli, R.; Murad, M.; W.M, W.; Haris, H. Physicochemical properties and sensory acceptability of pineapples of different varieties and stages of maturity. Food Research 2019, 3, 491-500.

7. Almeida, E.; Souza, G.; Guedes, J.; Barbosa, I.; Sousa, C.; Cstellano, L.; Magnani, M.; Souza, E. Mentha piperita L. essential oil inactivates spoilage yeasts in fruit juices through the perturbation of different physiological functions in yeast cells. J. Food Micro. 2019, 82, 20-29, https://doi.org/10.1016/j.fm.2019.01.023.

8. Oniszczuk, A.; Agnieszka, W.; Tomasz, O.; Arkadiusz, M.; Ahlem, D.; Ewa, M. Opuntia Fruits as Food Enriching Ingredient, the First Step towards New Functional Food Products. Molecules 2020, 25, https://doi.org/10.3390/molecules25040916.

9. Berrabah, H.; Taïbi, K.; Ait Abderrahim, L.; Boussaid, M. Phytochemical composition and antioxidant properties of prickly pear (Opuntia ficus-indica L.) flowers from the Algerian germplasm. Journal of Food Measurement and Characterization 2019, 13, 1166-1174, https://doi.org/10.1007/s11694-019-00032-8.

10. Hallim, A.M.; Rabie, A.; El-Shewey, M.A.; Abdel-Ghany, A.S. Evaluation Of Physico-Chemical Properties And Antioxidant Activity Of Stirred Yoghurt Fortified With Pomegranate And Cactus Pear Juices. Zagazig Journal of Agricultural Research 2019, 46, 1995-2008, https://doi.org/10.21608/zjar.2019.51918.

11. Gouws, C.A.; Georgousopoulou, E.N.; Mellor, D.D.; McKune, A.; Naumovski, N. Effects of the Consumption of Prickly Pear Cacti (Opuntia spp.) and its Products on Blood Glucose Levels and Insulin: A Systematic Review. Medicina 2019, 55, https://doi.org/10.3390/medicina55050138. 
12. Zenteno-Ramirez, G.; Juárez-Flores, B.I.; Aguirre-Rivera, J.R.; Monreal-Montes, M.; García, J.M.; Serratosa, M.P.; Santos, M.V.; Pérez, M.D.O.; Rendon-Huerta, J.A. Juices of prickly pear fruits (Opuntia spp.) as functional foods. Italian Journal of Food Science 2018, 30, 614-627, https://doi.org/10.14674/IJFS-921.

13. Salehi, E.; Emam-Djomeh, Z.; Askari, G.; Fathi, M. Opuntia ficus indica fruit gum: Extraction, characterization, antioxidant activity and functional properties. Carbohydrate Polymers 2019, 206, 565-572, https://doi.org/10.1016/j.carbpol.2018.11.035.

14. Oniszczuk, T.; Widelska, G.; Oniszczuk, A.; Kasprzak, K.; Wójtowicz, A.; Olech, M.; Nowak, R.; Kulesza, K.W.; Jóźwiak, G.; Hajnos, M.W. Influence of Production Parameters on the Content of Polyphenolic Compounds in Extruded Porridge Enriched with Chokeberry Fruit (Aronia melanocarpa (Michx.) Elliott). Open Chemistry 2019, 17, 166-176, https://doi.org/10.1515/chem-2019-0019.

15. Joshi, S.; Singh, A.; Laobangdisa, S.B.; Kulkarni, S.J.A.J.O.D.; Research, F. Utilization of prickly pear for preparation of fruit dessert. Asian J. Dair. Food Res. 2020, 39, 58-65, https://doi.org/10.18805/ajdfr.DR1476.

16. Aiello, A.; Di Bona, D.; Candore, G.; Carru, C.; Zinellu, A.; Di Miceli, G.; Nicosia, A.; Gambino, C.M.; Ruisi, P.; Caruso, C.; Vasto, S.; Accardi, G. Targeting Aging with Functional Food: Pasta with Opuntia Single-Arm Pilot Study. Rejuvenation Research 2017, 21, 249-256, https://doi.org/10.1089/rej.2017.1992.

17. Priyadarshani, S.V.G.N.; Cai, H.; Zhou, Q.; Liu, Y.; Cheng, Y.; Xiong, J.; Patson, D.L.; Cao, S.; Zhao, H.; Qin, Y. An Efficient Agrobacterium Mediated Transformation of Pineapple with GFP-Tagged Protein Allows Easy, Non-Destructive Screening of Transgenic Pineapple Plants. Biomolecules 2019, 9, 1-12, https://doi.org/10.3390/biom9100617.

18. Yang, F.; Wang, Y.-P.; Zhao, H.J.F.S.; Technology. Quality enhancement of fermented vegetable juice by probiotic through fermented yam juice using Saccharomyces cerevisiae. Food Sci. Techn., Campinas. 2020, 40, 26-35, https://doi.org/10.1590/fst.29918.

19. Kahraman, O.; Feng, H. Continuous-flow manothermosonication treatment of apple-carrot juice blend: Effects on juice quality during storage. LWT 2021, 137, https://doi.org/10.1016/j.lwt.2020.110360.

20. Olaniran, A.F.; Afolabi, R.O.; Abu, H.E.; Owolabi, A.; Iranloye, Y.M.; Okolie, C.E. Lime potentials as biopreservative as alternative to chemical preservatives in pineapple, orange and watermelon juice blend. Food Research 2020, 4, 1878-1884, https://doi.org/10.26656/fr.2017.4(6).057.

21. Hassen, Y.; Derese, T.; Belay, H. Effect of Blending Ratio of Pineapple on Sensory and Physicochemical Property of Mango Juice. J. Biop. Biotech. 2020, 10.

22. Shui, M.; Feng, T.; Tong, Y.; Zhuang, H.; Lo, C.; Sun, H.; Chen, L.; Song, S. Characterization of Key Aroma Compounds and Construction of Flavor Base Module of Chinese Sweet Oranges. Molecules 2019, 24, 1-13, https://doi.org/10.3390/molecules24132384.

23. Vollmer, K.; Czerny, M.; Vásquez-Caicedo, A.L.; Varona Iglesias, S.; Frank, J.; Carle, R.; Steingass, C.B. Non-thermal processing of pineapple (Ananas comosus [L.] Merr.) juice using continuous pressure change technology (PCT): HS-SPME-GC-MS profiling, descriptive sensory analysis, and consumer acceptance. Food Chemistry 2021, 345, https://doi.org/10.1016/j.foodchem.2020.128786.

24. Zhu, G.; Yu, G. A pineapple flavor imitation by the note method. Ciência e Tecnologia de Alimentos 2020 , 40, 924-928, https://doi.org/10.1590/fst.26019.

25. Ibraheim, g.E.; Elwakeel, M.A.; Hussein, A.S. Evaluation of quality attributes, antioxidant activity and volatile compounds of two cactus pear juices blended with guava juice. Egyptian Journal of Chemistry 2021, 64, 2613-2622, https://doi.org/10.21608/EJCHEM.2021.58555.3263.

26. Association of Official Analytical Chemists (AOAC). Official methods of analysis of the AOAC international, $20^{\text {th }}$ ed., Maryland: Rockville, 2016.

27. Ranganna, S. Hand book of analysis and quality control for fruits and vegetables product. Tata McGraw-Hill publishing company limited. New delhi, 2003; pp. 11-12.

28. Meydav, S.; Saguy, I.; Kopelman, I.J. Browning determination in citrus products. Journal of Agricultural and Food Chemistry 1977, 25, 602-604, https://doi.org/10.1021/jf60211a030.

29. Rattanathanalerk, M.; Chiewchan, N.; Srichumpoung, W. Effect of thermal processing on the quality loss of pineapple juice. Journal of Food Engineering 2005, 66, 259-265, https://doi.org/10.1016/j.jfoodeng.2004.03.016.

30. Cruz, N.; Capellas, M.; Hernández, M.; Trujillo, A.J.; Guamis, B.; Ferragut, V. Ultra high pressure homogenization of soymilk: Microbiological, physicochemical and microstructural characteristics. Food Research International 2007, 40, 725-732, https://doi.org/10.1016/j.foodres.2007.01.003.

31. Rababah, T.M.; Al-Mahasneh, M.A.; Kilani, I.; Yang, W.; Alhamad, M.N.; Ereifej, K.; Al-u'datt, M. Effect of jam processing and storage on total phenolics, antioxidant activity, and anthocyanins of different fruits. Journal of the Science of Food and Agriculture 2011, 91, 1096-1102, https://doi.org/10.1002/jsfa.4289.

32. Oniszczuk, A.; Oniszczuk, T.; Wójtowicz, A.; Wojtunik, K.; Kwaśniewska, A.; Waksmundzka-Hajnos, M. Radical scavenging activity of extruded corn gruels with addition of linden inflorescence. Open Chemistry 2015, 13, 1101-1107, https://doi.org/10.1515/chem-2015-0118.

33. Ayoola, G.; Ipav, S.; Solidiya, M.; Adepoju-Bello, A.; Coker, H.; Odugbemi, T. Phytochemical screening and free radical scavenging activities of the fruits and leaves of Allanblackia floribunda olive (Guttiferae). Inter. J. Health Res. 2008, 1, 81-93, https://doi.org/10.4314/ijhr.v1i2.47920. 
34. Goula, A.M.; Adamopoulos, K.G. Stability of lycopene during spray drying of tomato pulp. LWT - Food Science and Technology 2005, 38, 479-487, https://doi.org/10.1016/j.lwt.2004.07.020.

35. Moussa-Ayoub, T.E.; El-Samahy, S.K.; Rohn, S.; Kroh, L.W. Flavonols, betacyanins content and antioxidant activity of cactus Opuntia macrorhiza fruits. Food Research International 2011, 44, 2169-2174, https://doi.org/10.1016/j.foodres.2011.02.014.

36. Re, R.; Pellegrini, N.; Proteggente, A.; Pannala, A.; Yang, M.; Rice-Evans, C. Antioxidant activity applying an improved ABTS radical cation decolorization assay. Free Radical Biology and Medicine 1999, 26, 12311237, https://doi.org/10.1016/S0891-5849(98)00315-3.

37. Islam, M.A.; Ahmad, I.; Ahmed, S.; Sarker, A. Biochemical composition and shelf life study of mixed fruit juice from orange \& pineapple. Journal of Environmental Science and Natural Resources 2014, 7, 227-232, https://doi.org/10.3329/jesnr.v7i1.22175.

38. Olaniran, A.; Okolie, C.; Abu, H.; Afolabi, R.; Owolabi, A. Preservative Effect of Garlic-ginger, Sodium Benzoate and Ascorbic Acid in Unpasteurized Cashew Apple Juice. Asian J. Sci. Res. 2019, 12, 414-420, https://doi.org/10.3923/ajsr.2019.414.420.

39. Adams, R. Identification of essential oils components by gas chromatography/quadruple mass spectroscopy. Allured Publishing Corporation, Illinois, USA. 2007.

40. Wahua, T.A.T. Applied statistics for scientific studies. Afrika-Link Books, Nigeria 1999; pp. 250-287, https://doi.org/10.12691/ajfst-4-2-3.

41. El-Samahy, S.K.; Abd El-Hady, E.A.; Habiba, R.A.; Moussa-Ayoub, T.E. Some functional, chemical, and sensory characteristics of cactus pear rice-based extrudates. Journal of the Professional Association for Cactus Development 2007, 9, 136-147.

42. Karabagias, V.K.; Karabagias, I.K.; Prodromiti, M.; Gatzias, I.; Badeka, A. Bio-functional alcoholic beverage preparation using prickly pear juice and its pulp in combination with sugar and blossom honey. Food Bioscience 2020, 35, https://doi.org/10.1016/j.fbio.2020.100591.

43. Jan, A.; Masih, E. Development and quality evaluation of pineapple juice blend with carrot and orange juice. Inter. J. Sci. Res. Publ. 2012, 2, 1-8.

44. Begum, S.; Das, P.; Karmoker, P. Processing of mixed fruit juice from mango, orange and pineapple. Fund. Applied Agric. 2018, 3, 440-445, https://doi.org/10.5455/faa.289995.

45. Bamidele, O.P.; Fasogbon, M.B. Chemical and antioxidant properties of snake tomato (Trichosanthes cucumerina) juice and Pineapple (Ananas comosus) juice blends and their changes during storage. Food Chemistry 2017, 220, 184-189, http://dx.doi.org/10.1016/j.foodchem.2016.10.013.

46. Mohd, H., Shamsudin, R.; Mohd Adzahan, N. Effects of UVC irradiation and thermal treatment on the physico-chemical properties and microbial reduction of clear and turbid tamarind juice. Inter. Food Res. J. 2016, 23, 107-112.

47. Reddy, S.; Sucharitha, K.; Jalarama, K.; Syamala, R.B. Development and evaluation of physico-chemical quality markers of opuntia and pineapple squash. Int. J. Adv. Res. 2017, 5, 941-950, http://dx.doi.org/10.21474/IJAR01/3239.

48. Shamsudin, R.; Mohd Adzahan, N.; Pui Yee, Y.; Mansor, A. Effect of repetitive ultraviolet irradiation on the physico-chemical properties and microbial stability of pineapple juice. Innovative Food Science \& Emerging Technologies 2014, 23, 114-120, https://doi.org/10.1016/j.ifset.2014.02.005.

49. Ndiaye, C.; Xu, S.-Y.; Wang, Z.; Ndoye, A.S. Optimization of processing parameters for natural cloudy mango (Mangifera indica L.) juice using pectolytic and cellulolytic enzymes. Fruits 2011, 66, 291-303, https://doi.org/10.1051/fruits/2011039.

50. Curi, P.N.; Almeida, A.B.d.; Tavares, B.d.S.; Nunes, C.A.; Pio, R.; Pasqual, M.; Souza, V.R.d. Optimization of tropical fruit juice based on sensory and nutritional characteristics. Food Science and technology 2017, 37, 308-314, https://doi.org/10.1590/1678-457x.24716.

51. Haslam, E. Practical polyphenols: From structure to molecular recognition and physiological action. Cambridge, UK: Cambridge University Press, 1998; pp. 420.

52. Moßhammer, M.R.; Stintzing, F.C.; Carle, R. Colour studies on fruit juice blends from Opuntia and Hylocereus cacti and betalain-containing model solutions derived therefrom. Food Research International 2005, 38, 975-981, https://doi.org/10.1016/j.foodres.2005.01.015.

53. Lajos, H.; Zoltán, P.k.; Andrea, L. Tomato Fruit Quality and Content Depend on Stage of Maturity. HortScience HortSci 2006, 41, 1400-1401, https://doi.org/10.21273/HORTSCI.41.6.1400.

54. Choudhary, A.; Kumar, V.; Kumar, S.; Majid, I.; Aggarwal, P.; Suri, S. 5-Hydroxymethylfurfural (HMF) formation, occurrence and potential health concerns: recent developments. Toxin Reviews 2020, 1-17, https://doi.org/10.1080/15569543.2020.1756857.

55. Pastoriza de la Cueva, S.; Álvarez, J.; Végvári, Á.; Montilla-Gómez, J.; Cruz-López, O.; Delgado-Andrade, C.; Rufián-Henares, J.A. Relationship between HMF intake and SMF formation in vivo: An animal and human study. Molecular Nutrition \& Food Research 2017, 61, https://doi.org/10.1002/mnfr.201600773.

56. Li, Z.; Yuan, Y.; Yao, Y.; Wei, X.; Yue, T.; Meng, J. Formation of 5-hydroxymethylfurfural in industrialscale apple juice concentrate processing. Food Control 2019, 102, 56-68, https://doi.org/10.1016/J.FOODCONT.2019.03.021. 
57. Gaspar, E.M.S.M.; Lucena, A.F.F. Improved HPLC methodology for food control - furfurals and patulin as markers of quality. Food Chemistry 2009, 114, 1576-1582, https://doi.org/10.1016/j.foodchem.2008.11.097.

58. Al-Diab, D.; Jarkas, B. Effect of storage and thermal treatment on the quality of some local brands of honey from Latakia markets. J. Entom. Zool. Stud. 2015, 3, 328-334.

59. Siebert, K.J. Effects of Protein-Polyphenol Interactions on Beverage Haze, Stabilization, and Analysis. Journal of Agricultural and Food Chemistry 1999, 47, 353-362, https://doi.org/10.1021/jf980703o.

60. Baccouche, A.; Ennouri, M.; Felfoul, I.; Attia, H. A physical stability study of whey-based prickly pear beverages. Food Hydrocolloids 2013, 33, 234-244, https://doi.org/10.1016/j.foodhyd.2013.03.007.

61. Klimczak, I.; Małecka, M.; Szlachta, M.; Gliszczyńska-Świgło, A. Effect of storage on the content of polyphenols, vitamin $\mathrm{C}$ and the antioxidant activity of orange juices. Journal of Food Composition and Analysis 2007, 20, 313-322, https://doi.org/10.1016/j.jfca.2006.02.012.

62. Zulueta, A.; Esteve, M.J.; Frasquet, I.; Frígola, A. Vitamin C, vitamin A, phenolic compounds and total antioxidant capacity of new fruit juice and skim milk mixture beverages marketed in Spain. Food Chemistry 2007, 103, 1365-1374, https://doi.org/10.1016/j.foodchem.2006.10.052.

63. Yao, X.; Hu, H.; Qin, Y.; Liu, J. Development of antioxidant, antimicrobial and ammonia-sensitive films based on quaternary ammonium chitosan, polyvinyl alcohol and betalains-rich cactus pears (Opuntia ficusindica) extract. Food Hydrocolloids 2020, 106, https://doi.org/10.1016/j.foodhyd.2020.105896.

64. Prior, R.L.; Wu, X.; Schaich, K. Standardized Methods for the Determination of Antioxidant Capacity and Phenolics in Foods and Dietary Supplements. Journal of Agricultural and Food Chemistry 2005, 53, 42904302, https://doi.org/10.1021/jf0502698.

65. Belviranlı, B.; Al-Juhaimi, F.; Özcan, M.M.; Ghafoor, K.; Babiker, E.E.; Alsawmahi, O.N. Effect of location on some physico-chemical properties of prickly pear (Opuntia ficus-indica L.) fruit and seeds. Journal of Food Processing and Preservation 2019, 43, https://doi.org/10.1111/jfpp.13896.

66. Juhaimi, F.A.; Ghafoor, K.; Uslu, N.; Mohamed Ahmed, I.A.; Babiker, E.E.; Özcan, M.M.; Fadimu, G.J. The effect of harvest times on bioactive properties and fatty acid compositions of prickly pear (Opuntia ficusbarbarica A. Berger) fruits. Food Chemistry 2020, 303, https://doi.org/10.1016/j.foodchem.2019.125387.

67. Jeong, H.; Byoung, H.; Zhou, W.; Liu, X.; Song, Y.; Chang, M. Enzymatic deglycosylation of Opuntia ficus indica improves its estrogen receptor-subtype selective transcriptional and antiinflammatory activities. $J$. Nutri. Food Sci. 2016, 6, 1-9.

68. de la Rosa, L.A.; Moreno-Escamilla, J.O.; Rodrigo-García, J.; Alvarez-Parrilla, E. Chapter 12 - Phenolic Compounds. In: Postharvest Physiology and Biochemistry of Fruits and Vegetables. Yahia, E.M. Ed., Woodhead Publishing: 2019; pp. 253-271, https://doi.org/10.1016/C2016-0-04653-3.

69. Gan, R.-Y.; Chan, C.-L.; Yang, Q.-Q.; Li, H.-B.; Zhang, D.; Ge, Y.-Y.; Gunaratne, A.; Ge, J.; Corke, H. 9 Bioactive compounds and beneficial functions of sprouted grains. In: Sprouted Grains. Feng, H.; Nemzer, B.; DeVries, J.W. Eds.; AACC International Press: 2019; pp. 191-246, https://doi.org/10.1016/B978-0-12811525-1.00009-9.

70. Zafra-Rojas, Q.Y.; Cruz-Cansino, N.; Ramírez-Moreno, E.; Delgado-Olivares, L.; Villanueva-Sánchez, J.; Alanís-García, E. Effects of ultrasound treatment in purple cactus pear (Opuntia ficus-indica) juice. Ultrasonics Sonochemistry 2013, 20, 1283-1288, https://doi.org/10.1016/j.ultsonch.2013.01.021.

71. Aadil, M.; Zeng, X.; Han, Z.; Sun, D. Effects of ultrasound treatments on quality of grapefruit juice. Food Chem. 2013, 141, 3201-3206, https://doi.org/10.1016/j.foodchem.2013.06.008.

72. Nadeem, M.; Ubaid, N.; Qureshi, T.M.; Munir, M.; Mehmood, A. Effect of ultrasound and chemical treatment on total phenol, flavonoids and antioxidant properties on carrot-grape juice blend during storage. Ultrasonics Sonochemistry 2018, 45, 1-6, https://doi.org/10.1016/j.ultsonch.2018.02.034.

73. Abdel-Hameed, E.-S.S.; Nagaty, M.A.; Salman, M.S.; Bazaid, S.A. Phytochemicals, nutritionals and antioxidant properties of two prickly pear cactus cultivars (Opuntia ficus indica Mill.) growing in Taif, KSA. Food Chemistry 2014, 160, 31-38, https://doi.org/10.1016/j.foodchem.2014.03.060.

74. Yahia, E.M.; Mondragon-Jacobo, C. Nutritional components and antioxidant capacity of ten cultivars and lines of cactus pear fruit (Opuntia spp.). Food Research International 2011, 44, 2311-2318, https://doi.org/10.1016/j.foodres.2011.02.042.

75. Huang, D.; Ou, B.; Prior, R.L. The Chemistry behind Antioxidant Capacity Assays. Journal of Agricultural and Food Chemistry 2005, 53, 1841-1856, https://doi.org/10.1021/jf030723c.

76. Stinco, C.M.; Pumilia, G.; Giuffrida, D.; Dugo, G.; Meléndez-Martínez, A.J.; Vicario, I.M. Bioaccessibility of carotenoids, vitamin A and $\alpha$-tocopherol, from commercial milk-fruit juice beverages: Contribution to the recommended daily intake. Journal of Food Composition and Analysis 2019, 78, 24-32, https://doi.org/10.1016/j.jfca.2019.01.019.

77. Steingass, C.B.; Vollmer, K.; Lux, P.E.; Dell, C.; Carle, R.; Schweiggert, R.M. HPLC-DAD-APCI-MSn analysis of the genuine carotenoid pattern of pineapple (Ananas comosus [L.] Merr.) infructescence. Food Research International 2020, 127, https://doi.org/10.1016/j.foodres.2019.108709.

78. Dias, M.G.; Olmedilla-Alonso, B.; Hornero-Méndez, D.; Mercadante, A.Z.; Osorio, C.; Vargas-Murga, L.; Meléndez-Martínez, A.J. Comprehensive Database of Carotenoid Contents in Ibero-American Foods. A Valuable Tool in the Context of Functional Foods and the Establishment of Recommended Intakes of 
Bioactives. Journal of Agricultural and Food Chemistry 2018, 66, 5055-5107, https://doi.org/10.1021/acs.jafc.7b06148.

79. García-Cayuela, T.; Gómez-Maqueo, A.; Guajardo-Flores, D.; Welti-Chanes, J.; Cano, M.P. Characterization and quantification of individual betalain and phenolic compounds in Mexican and Spanish prickly pear (Opuntia ficus-indica L. Mill) tissues: A comparative study. Journal of Food Composition and Analysis 2019, 76, 1-13, https://doi.org/10.1016/j.jfca.2018.11.002.

80. Madrigal-Santillán, E.; García-Melo, F.; Morales-González, J.A.; Vázquez-Alvarado, P.; Muñoz-Juárez, S.; Zuñiga-Pérez, C.; Sumaya-Martínez, M.T.; Madrigal-Bujaidar, E.; Hernández-Ceruelos, A. Antioxidant and Anticlastogenic Capacity of Prickly Pear Juice. Nutrients 2013, 5, https://doi.org/10.3390/nu5104145.

81. Leopoldini, M.; Russo, N.; Toscano, M. The molecular basis of working mechanism of natural polyphenolic antioxidants. Food Chemistry 2011, 125, 288-306, https://doi.org/10.1016/j.foodchem.2010.08.012.

82. Chavez-Santoscoy, R.A.; Gutierrez-Uribe, J.A.; Serna-Saldívar, S.O. Phenolic Composition, Antioxidant Capacity and In Vitro Cancer Cell Cytotoxicity of Nine Prickly Pear (Opuntia spp.) Juices. Plant Foods for Human Nutrition 2009, 64, 146-152, https://doi.org/10.1007/s11130-009-0117-0.

83. Katanić, J.; Yousfi, F.; Caruso, M.C.; Matić, S.; Monti, D.M.; Loukili, E.H.; Boroja, T.; Mihailović, V.; Galgano, F.; Imbimbo, P.; Petruk, G.; Bouhrim, M.; Bnouham, M.; Ramdani, M. Characterization of bioactivity and phytochemical composition with toxicity studies of different Opuntia dillenii extracts from Morocco. Food Bioscience 2019, 30, https://doi.org/10.1016/j.fbio.2019.04.011.

84. Gómez-Maqueo, A.; García-Cayuela, T.; Welti-Chanes, J.; Cano, M.P. Enhancement of antiinflammatory and antioxidant activities of prickly pear fruits by high hydrostatic pressure: A chemical and microstructural approach. Innovative Food Science \& Emerging Technologies 2019, 54, 132-142, https://doi.org/10.1016/j.ifset.2019.04.002.

85. Galati, E.M.; Mondello, M.R.; Giuffrida, D.; Dugo, G.; Miceli, N.; Pergolizzi, S.; Taviano, M.F. Chemical Characterization and Biological Effects of Sicilian Opuntia ficus indica (L.) Mill. Fruit Juice: Antioxidant and Antiulcerogenic Activity. Journal of Agricultural and Food Chemistry 2003, 51, 4903-4908, https://doi.org/10.1021/jf030123d.

86. Bouzoubaâ, Z.; Essoukrati, Y.; Tahrouch, S.; Hatimi, A.; Gharby, S.; Harhar, H. Phytochemical study of prickly pear from southern Morocco. Journal of the Saudi Society of Agricultural Sciences 2016, 15, 155161, https://doi.org/10.1016/j.jssas.2014.09.002.

87. Zulueta, A.; Barba, F.J.; Esteve, M.J.; Frígola, A. Changes in Quality and Nutritional Parameters During Refrigerated Storage of an Orange Juice-Milk Beverage Treated by Equivalent Thermal and Non-thermal Processes for Mild Pasteurization. Food and Bioprocess Technology 2013, 6, 2018-2030, https://doi.org/10.1007/s11947-012-0858-X.

88. Quines-Lagmay, V.C.; Jeong, B.-G.; Kerr, W.L.; Choi, S.-G.; Chun, J. Antioxidative properties of eastern prickly pear (Opuntia humifusa) fermented with lactic acid bacteria and cell wall-hydrolyzing enzymes. $L W T$ 2020, 122, https://doi.org/10.1016/j.lwt.2020.109029.

89. Herbach, K.M.; Stintzing, F.C.; Carle, R. Betalain Stability and Degradation-Structural and Chromatic Aspects. Journal of Food Science 2006, 71, R41-R50, https://doi.org/10.1111/j.1750-3841.2006.00022.x.

90. Smuda, M.; Glomb, M.A. Maillard Degradation Pathways of Vitamin C. Angewandte Chemie International Edition 2013, 52, 4887-4891, https://doi.org/10.1002/anie.201300399.

91. Kanzler, C.; Haase, P.T.; Kroh, L.W. Antioxidant Capacity of 1-Deoxy-d-erythro-hexo-2,3-diulose and darabino-Hexo-2-ulose. Journal of Agricultural and Food Chemistry 2014, 62, 2837-2844, https://doi.org/10.1021/jf404322r.

92. Rufián-Henares, J.A.; Morales, F.J. Functional properties of melanoidins: In vitro antioxidant, antimicrobial and antihypertensive activities. Food Research International 2007, 40, 995-1002, https://doi.org/10.1016/j.foodres.2007.05.002.

93. Joy, K.; Rani, R. Formulation, sensory evaluation and nutrient analysis of products with Aloe vera. World J. Pharm. and Pharmac. Sci. 2013, 2, 5321-5328.

94. Rahman, M.; Markad, M.L.; Kulkarni, T.S.; Meghdambar, P.V. Sensory Attributes of the Mixed Fruit Jam made from Aloe Vera, Pineapple and Mango. Inter. J. Sci. Res. 2014, 4, 408-412.

95. Mohd Ali, M.; Hashim, N.; Abd Aziz, S.; Lasekan, O. Pineapple (Ananas comosus): A comprehensive review of nutritional values, volatile compounds, health benefits, and potential food products. Food Research International 2020, 137, https://doi.org/10.1016/j.foodres.2020.109675.

96. Martínez, R.; Natalia, V.; Juan, M.; Johannes, B. Aroma characterization of grape juiceenriched with grapevine by-products using thermomaceration. Chil J. Agric. Res. 2017, 77, 234-242, https://doi.org/10.4067/S0718-58392017000300234.

97. Andreu-Coll, L.; Noguera-Artiaga, L.; Carbonell-Barrachina, Á.A.; Legua, P.; Hernández, F. Volatile composition of prickly pear fruit pulp from six Spanish cultivars. Journal of Food Science 2020, 85, 358363, https://doi.org/10.1111/1750-3841.15001.

98. Mahmud, M.M.C.; Shellie, R.A.; Keast, R. Unravelling the relationship between aroma compounds and consumer acceptance: Coffee as an example. Comprehensive Reviews in Food Science and Food Safety 2020, 19, 2380-2420, https://doi.org/10.1111/1541-4337.12595. 
99. Ikram, M.M.; Ridwani, S.; Putri, S.P.; Fukusaki, E. GC-MS Based Metabolite Profiling to Monitor RipeningSpecific Metabolites in Pineapple (Ananas comosus). Metabolites 2020, 10, 1-15, https://doi.org/10.3390/metabo10040134.

100. Kaewtathip, T.; Charoenrein, S. Changes in volatile aroma compounds of pineapple (Ananas comosus) during freezing and thawing. International Journal of Food Science \& Technology 2012, 47, 985-990, https://doi.org/10.1111/j.1365-2621.2011.02931.x.

101.S Steingass, C.B.; Dell, C.; Lieb, V.; Mayer-Ullmann, B.; Czerny, M.; Carle, R. Assignment of distinctive volatiles, descriptive sensory analysis and consumer preference of differently ripened and post-harvest handled pineapple (Ananas comosus [L.] Merr.) fruits. European Food Research and Technology 2016, 242, 33-43, https://doi.org/10.1007/s00217-015-2515-x.

102.Lasekan, O.; Hussein, F.K. Classification of different pineapple varieties grown in Malaysia based on volatile fingerprinting and sensory analysis. Chemistry Central Journal 2018, 12, 1-12, https://doi.org/10.1186/s13065-018-0505-3.

103.Zahi, M.R.; Liang, H.; Yuan, Q. Improving the antimicrobial activity of d-limonene using a novel organogelbased nanoemulsion. Food Control 2015, 50, 554-559, http://doi.org/10.1016/J.FOODCONT.2014.10.001.

104.Arena, E.; Campisi, S.; Fallico, B.; Lanza, M.C.; Maccarone, E.J.I.J.O.F.S. Aroma value of volatile compounds of prickly pear (Opuntia ficus indica (L.) Mill., Cactaceae). Italian J. Food Sci. 2001, 13, 311319.

105.Högnadóttir, Á.; Rouseff, R.L. Identification of aroma active compounds in orange essence oil using gas chromatography-olfactometry and gas chromatography-mass spectrometry. Journal of Chromatography A 2003, 998, 201-211, https://doi.org/10.1016/S0021-9673(03)00524-7.

106. Rassis, D.; Saguy, I.S. Kinetics of aseptic concentrated orange juice quality changes during commercial processing and storage. International Journal of Food Science \& Technology 1995, 30, 191-198, https://doi.org/10.1111/j.1365-2621.1995.tb01371.x.

107.Perez-Cacho, P.R.; Rouseff, R. Processing and Storage Effects on Orange Juice Aroma: A Review. Journal of Agricultural and Food Chemistry 2008, 56, 9785-9796, https://doi.org/10.1021/jf801244j.

108. Steingass, C.B.; Glock, M.P.; Lieb, V.M.; Carle, R. Light-induced alterations of pineapple (Ananas comosus [L.] Merr.) juice volatiles during accelerated ageing and mass spectrometric studies into their precursors. Food Research International 2017, 100, 366-374, http://dx.doi.org/10.1016/j.foodres.2017.06.030.

109. Adiani, V.; Gupta, S.; Variyar, P.S. Microbial quality assessment of minimally processed pineapple using GCMS and FTIR in tandem with chemometrics. Scientific Reports 2020, 10, 1-9, https://doi.org/10.1038/s41598-020-62895-y.

110. Osman, R. Optimization of Headspace Solid Phase Microextraction (HS-SPME) for the Extraction of Volatile Organic Compounds (VOCs) in MD2 Pineapple. Science Letters 2020, 14, 58-70.

111.de Souza, W.F.M.; Mariano, X.M.; Isnard, J.L.; de Souza, G.S.; de Souza Gomes, A.L.; de Carvalho, R.J.T.; Rocha, C.B.; Junior, C.L.S.; Moreira, R.F.A. Evaluation of the volatile composition, toxicological and antioxidant potentials of the essential oils and teas of commercial Chilean boldo samples. Food Research International 2019, 124, 27-33, https://doi.org/10.1016/j.foodres.2018.12.059.

112. Mariano, X.M.; de Souza, W.F.M.; Rocha, C.B.; Moreira, R.F.A. Bioactive volatile fraction of Chilean boldo (Peumus boldus Molina) - an overview. Journal of Essential Oil Research 2019, 31, 474-486, https://doi.org/10.1080/10412905.2019.1617797.

113. Hashizume, M.; Gordon, M.H.; Mottram, D.S. Light-Induced Off-flavor Development in Cloudy Apple Juice. Journal of Agricultural and Food Chemistry 2007, 55, 9177-9182, https://doi.org/10.1021/jf0715727.

114.Brito, T.B.N.; R.S. Lima, L.; B. Santos, M.C.; A. Moreira, R.F.; Cameron, L.C.; C. Fai, A.E.; S.L. Ferreira, M. Antimicrobial, antioxidant, volatile and phenolic profiles of cabbage-stalk and pineapple-crown flour revealed by GC-MS and UPLC-MSE. Food Chemistry 2021, 339, https://doi.org/10.1016/j.foodchem.2020.127882.

115.Saenz, C. Processing technologies: an alternative for cactus pear (Opuntia spp.) fruits and cladodes. Journal of Arid Environments 2000, 46, 209-225, https://doi.org/10.1006/jare.2000.0676.

116.Xi, W.-P.; Zhang, B.O.; Liang, L.I.; Shen, J.-Y.; Wei, W.-W.; Xu, C.-J.; Allan, A.C.; Ferguson, I.B.; Chen, K.-S. Postharvest temperature influences volatile lactone production via regulation of acyl-CoA oxidases in peach fruit. Plant, Cell \& Environment 2012, 35, 534-545, https://doi.org/10.1111/j.13653040.2011.02433.x.

117.Steingass, C.B.; Grauwet, T.; Carle, R. Influence of harvest maturity and fruit logistics on pineapple (Ananas comosus [L.] Merr.) volatiles assessed by headspace solid phase microextraction and gas chromatographymass spectrometry (HS-SPME-GC/MS). Food Chemistry 2014, 150, 382-391, https://doi.org/10.1016/j.foodchem.2013.10.092. 